\title{
Environmental aspects of insect mass production
}

\author{
S. Smetana", R. Spykman and V. Heinz \\ German Institute of Food Technologies (DIL e.V.), Professor-von-Klitzing-Straße 7, 49610 Quakenbrück, Germany; \\ s.smetana@dil-ev.de
}

Received: 7 September 2020 / Accepted: 11 December 2020

(c) 2021 Wageningen Academic Publishers

OPEN ACCESS CP) (1) REVIEW ARTICLE

\begin{abstract}
Mass production of insects is calling for environmentally optimised and economically efficient insect value chains. It is a complex task considering a great variety in insect species, production scales, feed formulations, etc. Taking a challenge of environmental impact clarification, a few studies highlight on life cycle assessment (LCA) of insect production. The current study is aimed to systemise 24 selected previous studies to establish a modular framework for the determination of contribution of sustainability assessment factors of insect production chains. Reviewing published studies according to the elements of LCA, the study identified a feasible approach for the modelling of insect production chains, which can be used for the facilitation of comparability of further LCA studies. The approach is based on a modular analysis of insect production through a graphical mapping of value chains (allowed identification of precise system boundaries) supplemented with table analysis considering scale of production, reference (functional) unit, impact assessment methodology and type of LCA. Such an approach allows for consistency in LCA setting and further comparability of results.
\end{abstract}

Keywords: life cycle assessment, insect production chains, insect mass production, environmental optimisation, material flow analysis, sustainability

\section{Introduction}

Food production is facing the challenging task of assuring food security within the planet's carrying capacity. The environmental impact of the current food system should be substantially decreased (Willett et al., 2019), which is extremely challenging considering the increasing demand for food in the next few decades (Gouel and Guimbard, 2019). The demand for protein sources and especially meat is projected to increase by $76 \%$ by 2050 in comparison to the basis year of 2005 (Alexandratos and Bruinsma, 2012), which will lead to critical environmental consequences. The search for alternative food and protein sources with lower environmental impact is becoming a vital task (Smetana et al., 2015, 2020a; Van der Weele et al., 2019) not only for the substitution of meat but also for animal protein feeds such as soybean meal and fishmeal (Van Huis et al., 2013; Veldkamp et al., 2012). Insects in this perspective are becoming an interesting potential solution not only for the challenges of protein supply for food and feed purposes (Van Huis et al., 2013), but also for food waste treatment and nutrient recirculation in food systems (Gold et al., 2020; Ites et al., 2020; Mertenat et al., 2019; Smetana, 2020).

While insects demonstrate the potential to deliver local and sustainable protein sources (Allegretti et al., 2018; Smetana et al., 2019b), the young industry of mass insect production in Western countries is still facing difficulties of setting up sustainable production starting from the design phase. There is a problem associated with data availability, which can be used for the comprehensive analysis. From one side small scale insect producers do not gather detailed data on the processes, so the data often do not exist. From another part, insect producers do not open data for the public use, so the data availability is lacking in comparison to well established feed and food industries (Bosch et al., 2019; Ites et al., 2020; Salomone et al., 2017), which poses a challenge to the industry's efficient design of a sustainable production system (Ites et al., 2020). At the same time assurance of sustainability (lower environmental impact) of insect products in comparison 
to conventional benchmarks on the market is crucial for the survival for insect mass production in Europe (Wade and Hoelle, 2020). Therefore, it is necessary to find ways for the reliable assessment of insect production at early industry development stages.

Life cycle thinking (LCT) (Fava, 1993) is a broad underlying concept, aimed at considering direct and indirect environmental impacts of complex systems, integrated into several related methods such as eco-efficiency, ecodesign and life cycle assessment (LCA). Special attention to futuristic estimates is devoted in anticipatory (Guinée et al., 2018), scenario-based (Fukushima and Hirao, 2002), consequential (Zamagni et al., 2012), prospective or ex-ante LCA (Buyle et al., 2019; Cucurachi et al., 2018; Spielmann et al., 2005; Walser et al., 2011). They all are oriented to provide certain insights on the potential future outcomes. It should be considered that any type of prediction will include the accounting of the uncertainty, which would complicate the calculations. In order to deal with complexity issues prospective LCAs can be streamlined using a modular approach (Steubing et al., 2016). Modularity of impact assessment allows for approximation of missing data values and automation of analysis (Steubing et al., 2016). It is a basic concept integrated in modern LCA methods, which allows for the integrated and disintegrated analysis of production and supply chains, finding the impact hotspots and modelling of scenario effects. At the same time modularisation is not applied to insect production chains up to date.

Therefore, the main aim of this review was to establish a modular framework for the determination of environmental contribution of different parts of insect production chains (modules) based on recent literature devoted to environmental impact assessment of insect production.

In order to achieve this aim, the objectives of the paper were:

- to review current approaches to the environmental impact assessment of insect production systems, defining hotspots and the contribution of environmental impacts;

- to classify and systemise relevant environmental impact factors for modular sustainability assessment of insect production chains;

- to propose a modular framework for LCA of insect production and processing.

The article is structured to comprehensively review current literature sources dealing with production of feed for insects, insect farming, processing, and insect-based products use for food and feed purposes. It starts with explaining and illustrating the concepts of LCT and LCA. Further, the paper addresses the environmental aspects of insect production chains according to the aggregated stages of production with the aim to define the impact hotspots and assessment limitation factors. It is finalised with an overview on a potential modular framework for LCA of insect production and processing.

\section{Study design}

This study relies on available studies dealing with the environmental impact of insect production for food and feed, but also includes studies performing LCA on insect application for waste treatment.

The selection of studies was performed via 'Google Scholar', 'Mendeley' and 'WorldWideScience' in the beginning of 2020 using keywords: 'life cycle assessment' 'LCA' insect production'. The search yielded 125 studies, which were reviewed for the connection with analysis of environmental impact of insect production. Specific criteria set for the selection of studies were that is should contain an original LCA model of insect-based production of feed or food, waste treatment or other system aimed for insect production. One output of insect production system is the insect biomass, which is quantified. Design of insect production system should include the reproduction cycles and not rely on natural oviposition or natural insect harvesting. The review excluded the studies which do not include reflection on mandatory elements of LCA: goal and scope definition, life cycle inventory (LCI), functional unit (FU), life cycle impact assessment (LCIA) methods and interpretation. The references of the articles suitable under defined criteria were also explored for consistency. The review then concentrated on the analysis of selected articles (24). The selected articles reviewed in this manuscript follow the life cycle approach and include insect production stages, upstream and in some cases downstream processes. They all define goal and scope, system boundaries, provide inventory data and draw conclusions on the impact of a product as well as hotspots of production.

The review article will follow the conceptual approach applied to all the LCA studies. All the subchapters start with defining the goal and scope, specifying the reasons for separation and analysis of the production stage (module), boundaries for the module and limitations of such selection. Furthermore, data availability and requirements will be analysed as well as potential approaches for data collection, validation and aggregation for the input and output data to quantify material use, energy use, environmental discharges, and waste associated with each module. The final part of modules and sub-modules analysis will include the analysis on the use of LCIA methods, categories, indicators, equivalency and contribution factors. Critical analysis on the interpretation of results and drawn conclusions in current studies will be a closing part. 


\section{Life cycle assessment}

LCT approach is aimed at a holistic conceptualisation of environmental issues (or other pillars of sustainability) at system level (Mont and Bleischwitz, 2007). LCT is a holistic approach, which examines the impacts of a product or a service through its entire life cycle from the extraction of raw materials (cradle), through production, use and final disposal or other end of life options (grave) (UNEP/ SETAC, 2012). It means that the sustainability analysis considers required resources and expected impacts of all life cycle stages (design, production, use and end of life). LCT provides a comprehensive basis for the analysis of indirect and rebound effects, allowing to eliminate unintended negative consequences associated with higher rates of consumption of environmentally efficient and cheaper products (Hertwich, 2008; Mont and Bleischwitz, 2007). Classical applications of LCA relate to the determination of environmental impact of product through the entire life cycle of a product, identification of environmental hot spots (stages with the highest contribution), product comparison, eco-design and other aspects. The comparison of alternative products and minimisation of trade-offs between them, for the selection of less environmentally impacting options (Cucurachi et al., 2019), became a 'golden' standard in environmental assessment of products and services. Moreover, LCA is a basis for Environmental Product Declaration (Del Borghi, 2013; Schau and Fet, 2008) and Product Environmental Footprint (Bach et al., 2018), included in the guidelines of European Commission for the environmental impact assessment and declaration (Allio, 2007). The development of the European guidelines further triggers practical application of LCA for business and management strategies, marketing and product labelling (Mont and Bleischwitz, 2007; Rubik and Frankl, 2017).

LCA is a complex method, which requires a high-level knowledge, related to the method and dealing with environmental impact concepts and guiding factors. ISO standards define four main stages of LCA: (1) goal and scope definition; (2) LCI; (3) LCIA; and (4) interpretation (ISO 14040, ISO 14044; ISO, 2006a,b). Any LCA should include information on FU, system boundaries, impact assessment methods and timeframe (Thabrew et al., 2009), but also details on assumptions, limitations, data quality and requirements, reference flows, etc. LCIA methods assign an impact factor to an elementary flow in the inventory, thus connecting the amount of resources used and emissions to the potential environmental impact caused (Zampori et al., 2016). Moreover, two main approaches in completing LCA should be outlined: attributional (information on environmental burden associated with the specific product life cycle) and consequential (information on environmental burden appearing because of decision making with consequences of the market changes) (UNEP/SETAC, 2011). Goal and scope of the study define the type of approach to be followed. Some studies focus on an attributional LCA, others on a consequential LCA, and others on both, attributional and consequential. Such conceptualisation allows for certain consistency between different studies and standardisation of results. Further chapters include a few examples on the indicated components in relation to insect production chains.

Modularity of LCA is foreseen as a feasible way of dealing with many variants in a product's life cycle (Jungbluth et al., 2000). The approach allows to assess multiple alternative value chains within a production system. In LCA a product's life cycle is modelled in various boundaries (depending on the goal and scope of the study: from cradle to grave, cradle to gate, gate to gate, etc.), to set some pre-conditions for the comparability of the studies in the same scope. To compare alternative value chains, each alternative life cycle needs to be modelled individually, even if changes were made only in one of the stages. By contrast, the fundamental idea of the modular LCA approach is to break down a production system or a product's life cycle into modules which can be recombined to form complete value chains (Steubing et al., 2016). These modules are practitionerdefined and encompass life cycle stages or unit processes. Besides elementary flows, the modules only have input and output flows which link them to other modules of the studied production system. This is achieved by expanding a module's foreground process(es) to include all required background processes (e.g. utilities, waste treatment, infrastructure). This procedure is repeated until the entire production system is described in modular LCI. Based on these modular LCIs, LCIA is carried out, leading to individual LCIA results for each module. The LCIA result for a value chain is determined by aggregating the LCIA results of the involved modules (Rebitzer, 2005).

When several modules within a production system produce substitutable products, alternative value chains arise. A module-product matrix contains information on how the modules can be connected to form alternative value chains, taking scaling factors and interdependencies into account (Steubing et al., 2016). An advantage compared to conventional LCA is that the modelling effort can be considerably lower, since it scales with the number of modules, not with the number of alternative value chains. However, the modular approach requires an up-front time investment for the modularisation, meaning the suitable definition of modules to represent key choices within the production system. Modular LCA can therefore streamline (aggregate) scenario analysis through the optimisation models, which allow for the identification of missing data points using optimisation algorithms (for example using Pareto optimisation). It can therefore not only enable optimisation of value chains by using the module data as inputs to optimisation models (Steubing et al., 2016) but also can provide solutions for the data limitations in the assessment of emerging technologies (Thomas et al., 2020). 


\section{Environmental hotspots of insect production}

Overall, the available studies rely on a few approaches towards the LCA of insect production. Most of the studies use an attributional approach for the analysis, aimed at the identification of hotspots and comparison with similar products (Table 1). Only two studies take first steps towards consequential assessment of insect production, indicating the difficulties and high uncertainty rates associated with assumptions concerning product substitutions on the market (Smetana et al., 2019b; Van Zanten et al., 2018).

Most studies employ multiple impact categories and characterisation factors (coefficient units allowing equivalent aggregation of the environmental interventions to a particular impact category) to analyse the environmental impact of insect production. A wide variety of impact assessment methods is used. Separate indicators are mostly calculated in early studies (Joensuu and Silvenius, 2017; Komakech et al., 2015; Oonincx and De Boer, 2012; Van Zanten et al., 2015), while other studies rely on more aggregated methodologies, allowing for the inclusion of multiple indicators and end-point aggregation (Table 1).

Setting the goal and scope of the study is of outmost importance for any LCA study, as mistakes at the selection of FU or system boundaries could lead to wrong results and justifications (Rebitzer et al., 2004). LCA studies of insect production chains are not exception. The general goal in the studies reflecting on the production of insects grown on conventional (commercial) feed is connected with identification of environmental impact of such production with certain comparison to similar protein production systems (Halloran et al., 2017; Oonincx and de Boer, 2012; Smetana et al., 2016, 2019b; Suckling et al., 2020) for food and feed purposes. Strong comparative approach based on a few FUs to conventional 'traditional' protein and fat sources is taken in studies of Smetana et al. (Smetana et al., 2015, 2016, 2019b, 2020a). Special attention in some studies is devoted to the identification of insect production impact if by-products are applied for the feeding (Bava et al., 2019; Maiolo et al., 2020) in these cases considering

Table 1. Life cycle impact assessment approaches in life cycle assessment studies of insect production.

\begin{tabular}{|c|c|c|c|}
\hline Study & $\begin{array}{l}\text { Impact categories } \\
\text { (characterisation factor) }^{1}\end{array}$ & Impact assessment method & $\begin{array}{l}\text { Attributional/ } \\
\text { consequential }\end{array}$ \\
\hline Smetana et al., 2020a & Multiple mid and endpoint & IMPACT 2002+ Version 2.21 & Atr \\
\hline Suckling et al., 2020 & Multiple midpoint & ILCD 2011 Midpoint+ method & Atr \\
\hline Ites et al., 2020 & Multiple mid and endpoint & IMPACT 2002+ Version 2.21 & Atr \\
\hline Maiolo et al., 2020 & GWP, AP, EP; CED, WU & CML-IA baseline V3.05, CED (Frischknecht et al. 2007); AWARE & Atr \\
\hline Roffeis et al., 2020 & Single score & ReCiPe method (V 1.11) & Atr \\
\hline Ulmer et al., 2020 & Multiple mid and endpoint & IMPACT 2002+ (V 2.11) & Atr \\
\hline Bava et al., 2019 & Multiple midpoint & ILCD 2011 Midpoint V1.03 & Atr \\
\hline Smetana et al., 2019b & Multiple mid and endpoint & IMPACT 2002+ and IMPACT World for WF; ReCiPe for sensitivity & Atr, Cons \\
\hline Van Zanten et al., 2018 & GWP, EU, LU & Separate indicators & Atr, Cons \\
\hline Mertenat et al., 2019 & GWP & ReCiPe Midpoint (H) & Atr? \\
\hline Bosch et al., 2019 & GWP, LU, EU & Separate indicators & Atr \\
\hline Thévenot et al., 2018 & CED, CC, AP, EP, LU & $\begin{array}{l}\text { CED was quantified using the Total Cumulative Energy Demand method } \\
\text { V1.8 (VDI, 1997). CC, AP, EP, and LU were calculated according to the } \\
\text { CML-IA baseline } 2000 \text { V2.03 method }\end{array}$ & Atr \\
\hline Halloran et al., 2017 & Multiple midpoint & ILCD method & Atr \\
\hline Roffeis et al., 2017 & Single score & ReCiPe method (V 1.11) & Atr \\
\hline Salomone et al., 2017 & GWP, LU, EU & $\begin{array}{l}\text { CML } 2 \text { baseline } 2000 \text { method and GWP 100a v. } 1.02 \text { method (IPPC, } \\
\text { 2007) }\end{array}$ & Atr \\
\hline Joensuu and Silvenius, 2017 & GWP & Separate indicators & Atr \\
\hline Smetana et al., 2016 & GWP, EU, LU; single score & ReCiPe V1.08 and IMPACT 2002+ & Atr \\
\hline Roffeis et al., 2015 & ALO, WD, FD & $\mathrm{ReCiPe} 2008$ & Atr \\
\hline Smetana et al., 2015 & Multiple mid and endpoint & IMPACT 2002+ & Atr \\
\hline Van Zanten et al., 2015 & GWP, EU, LU & Separate indicators & Atr \\
\hline Komakech et al., 2015 & GWP, EP, EU & Separate indicators & Atr \\
\hline Oonincx and De Boer, 2012 & GWP, LU, EU & Separate indicators & Atr \\
\hline
\end{tabular}

${ }^{1} \mathrm{ALO}=$ agricultural land occupation; $\mathrm{AP}=$ acidification potential; $\mathrm{CC}=$ climate change; $\mathrm{CED}=$ cumulative energy demand; $\mathrm{EP}=$ eutrophication potential; $\mathrm{EU}=$ energy use; $\mathrm{FD}$ = fossil depletion; $\mathrm{GWP}=$ global warming potential; $\mathrm{LU}=$ land use; $\mathrm{WD}=$ water depletion; $\mathrm{WU}=$ water use. 
insect production for feed or petfood purposes mostly (Bava et al., 2019; Maiolo et al., 2020; Smetana et al., 2016, 2019b; Thévenot et al., 2018). On the other hand, insects as by-product of honey production are analysed in study of Ulmer et al. (Ulmer et al., 2020). Separate goal is set in the studies dealing with insect production for waste treatment including manure treatment (Ites et al., 2020; Komakech et al., 2015; Mertenat et al., 2019; Roffeis et al., 2015; Salomone et al., 2017) and further animals grown on insects (Van Zanten et al., 2015). More prospective approach is presented in studies dealing with ex-ante and consequential assessment (Roffeis et al., 2017; Smetana et al., 2019b), and evaluation environmental performance of insect production in regional perspective (West Africa) (Roffeis et al., 2020).

Analysed studies rely on various FU (Bava et al., 2019; Salomone et al., 2017; Smetana et al., 2015, 2019b; Ulmer et al., 2020). Weight-based units dominate in the studies; however, they reflect different aspects of insect production. Some studies account for the weight the input materials in case of waste or manure treatment to determine efficiency of biotransformation(Ites et al., 2020; Komakech et al., 2015; Mertenat et al., 2019; Roffeis et al., 2015; Salomone et al., 2017). Studies dealing with production of insectbased feed (Maiolo et al., 2020; Roffeis et al., 2017, 2020; Thévenot et al., 2018; Van Zanten et al., 2015) or insectbased ingredients for food and feed purposes (Halloran et al., 2017; Smetana et al., 2015, 2016, 2019b; Suckling et al., 2020; Ulmer et al., 2020) rely on weight-based unit of output product (feed, meal, insects, dried insects). In order to consider nutritional properties of insects studies rely on comparison based on amount of proteins (Bosch et al., 2019; Halloran et al., 2017; Joensuu and Silvenius, 2017; Oonincx and De Boer, 2012; Salomone et al., 2017; Smetana et al., 2015, 2016, 2019b; Ulmer et al., 2020), lipids (Salomone et al., 2017; Smetana et al., 2019b, 2020a) or energy (Smetana et al., 2015).

The overall reliability of data in the analysed studies could be assessed as good, as a lot of studies relied on primary data for foreground processes of insect production (Bava et al., 2019; Halloran et al., 2017; Oonincx and De Boer, 2012; Roffeis et al., 2017, 2020; Salomone et al., 2017; Smetana et al., 2019b; Suckling et al., 2020; Thévenot et al., 2018; Ulmer et al., 2020), a few studies relied on mixed literature and primary measured data (Ites et al., 2020; Maiolo et al., 2020; Mertenat et al., 2019; Smetana et al., 2016). The studies, which have a hypothetical or review character relied on secondary modelled data or literature sources for the modelling of LCA (Bosch et al., 2019; Komakech et al., 2015; Roffeis et al., 2015; Smetana et al., 2015; Van Zanten et al., 2015).

The differences in the goal and scope between different studies indicate that it is not viable to compare the results between all of them, as system set for the prime quality insect biomass production would be different from the system oriented solely on waste treatment. A bright example could be the studies of Roffeis et al. (2015, $2017,2020)$ where the high impact of insect production could relate to a regional approach taken, not available in other studies. Selection of FUs applied in the studies demonstrate consistency with reliance on weight basis in most studies. Differences presented of weight units routed in the magnitude or concentration on various parts of insect production chains (input or output) can be levelled through the recalculation for the same unit. Reliability of data used for the LCA studies is assured using primary data from the production. If the direct measured data is not available, the studies rely on modelling or literature sources. In these cases, reliability and availability of data is of higher importance to be analysed.

\section{Feed for insects}

Type of feed selected (vegetable rests, compound feed, food waste, etc.) and properties of selected feed (nutrient content, moisture content) in a great degree define the performance and environmental impact of the insect production system (Bosch et al., 2019; Ites et al., 2020; Oonincx and De Boer, 2012; Smetana et al., 2016, 2019b). And this relation is not straightforward. High quality of feed for insects in many cases results in higher environmental impact, but also comparatively short growing cycles. While lower nutritional quality of insect feed (which could have a lower impact of production) results in smaller size of insects, longer growing cycles and higher conversion ratio (Bosch et al., 2019; Smetana et al., 2016). This is the first trade-off which producers should consider. Moreover, the system is further complicated with the potential of insect application for waste treatment. Treatment of food waste may result in environmentally beneficial results especially if the feeding substrate is of good nutritional quality (Bosch et al., 2019; Ites et al., 2020; Salomone et al., 2017; Smetana et al., 2016). Environmental impact of animal manure treatment with insect technologies could also result in positive or negative environmental impact depending on the impact of avoided treatment processes (Roffeis et al., 2017, 2020; Smetana, 2020; Smetana et al., 2016).

\section{Primary production of feed (feed ingredients)}

LCA studies of insect mass rearing rarely pay attention to the variations of feed production or to the side-streams (byproduct) allocation of impacts. A lot of insect producers rely on the commercial compound feeds due to the legislative limitations (Bosch et al., 2019). Thus, it is necessary to pay careful attention to modelling of feed crops harvesting and feed production. In case of commercial feed production, the boundaries for insect feed are comparable to those 
outlined for animal feeds (Bava et al., 2019; Bosch et al., 2019; Halloran et al., 2017; Smetana et al., 2016). The boundaries should include the classic agricultural stages of sowing, growing and harvesting with further processing into animal feed. High availability of data and previously performed analyses (McAuliffe et al., 2016; Papatryphon et al., 2004; Poore and Nemecek, 2018) make the assessment of insects produced on conventional feeds somewhat easier and flexible in terms of selection of LCIA methods and indicators. However, the reliability of data and previous studies should be thoroughly analysed for the consistency and representability.

Additionally, the boundaries for insect feed production sometimes include side-streams and secondary products from food processing or agriculture (Bava et al., 2019; Bosch et al., 2019; Ites et al., 2020; Maiolo et al., 2020; Smetana et al., 2016). It is envisioned that insect production in the future will even stronger rely on side-streams and secondary products from food processing or agriculture due to its potential for a constant supply (Smetana et al., $2019 b)$. In such cases the upstream production impacts should be allocated to the relevant by-product following physical or economic criteria (Ardente and Cellura, 2012). Formulations of feed for insects from food products at retail or consumer stages (wastes) should follow a dual approach - it should include all the impacts of upstream production and avoided waste treatment (Mondello et al., 2017; Salomone et al., 2017; Smetana et al., 2016).

Depending on the type of feed the LCA of this stage should rely on careful allocation or system expansion which to a great degree would determine the overall impact of insect production and further use of insect for food or feed (Smetana et al., 2019b; Van Zanten et al., 2018). The importance of this stage is connected also with limited availability of data on the processing characteristics and allocated value and impacts to the by-products. Published studies rely mostly on attributional approaches and economic or nutritional allocation (Table 1) and rarely on system expansion and consequences on the market (Smetana et al., 2019b; Van Zanten et al., 2018).

\section{Feed transportation and storage}

Insect feed transportation is performed by usual means of dry and liquid feed transport relying on road infrastructure (trucks, lorries, and tractors). Most studies rely on rather short distances for the feed delivery in the scope of 100$300 \mathrm{~km}$, which is justified due to the economic feasibility and availability of local suppliers (Bava et al., 2019; Maiolo et al., 2020; Smetana et al., 2016), unless feed contains soy, grown overseas (Halloran et al., 2017). It should be considered that in most cases transportation (along the whole production chain) contributes only a small share to the overall environmental impact, amounting to $2-6 \%$ of impact depending on the category (largest impacts in global warming potential, resource depletion and ozone depletion) and modelled scenario (distance, means of transportation). The share of feed transportation impact is increased in case of insect production on wastes - it can be responsible for up to 18\% of GWP (Salomone et al., 2017), however no increase is observed in absolute values. Most of the studies either model the delivery of feed or rely on existing databases for the analysis. Data availability is not a limiting factor for this assessment module.

\section{Secondary feed production and processing}

Feed and food processing stages are currently considered as very challenging to model due to the limitations in data availability, huge diversity of potential alternatives and diversity of application scales (Ites et al., 2020; Smetana et al., 2016, 2019b). Feed is mostly delivered to insects in dried or high-moisture forms. Dried feeds are supplied to mealworms, crickets, and grasshoppers, while moisturised feeds are prepared for larvae of flies. Dried feeds, sources from grains, require minimal processing which might consist of mixing, cutting and grinding. In some cases, additional sources of moisture like vegetables are supplied alongside the dried feeds (Halloran et al., 2017; Oonincx and De Boer, 2012). Moisturised feeds, on the other hand, might be derived from wetting dried feeds or they might be delivered in moist form from the supplier (wet mills, breweries, farms in case of manure, etc.). Similar to transportation, the impact of the feed processing stage is minimal and that is why in most cases feed processing is considered in rather aggregated form. Recently investigated options for insect feed pre-treatment (Isibika et al., 2019; Ravindran and Jaiswal, 2019) are not included in the examined LCA studies.

\section{Insect farming}

Insect farming together with insect biomass fractionation (separation of insect biomass into fractions including drying) are responsible for a considerable portion of environmental impact, which is reflected in the range of 15$70 \%$ depending on impact category and level of processing in LCA studies (Bava et al., 2019; Halloran et al., 2017; Maiolo et al., 2020; Smetana et al., 2016, 2019b; Thévenot et al., 2018). Thus, high importance in the impact contribution is highlighted for energy consumption. Literature indicated that 18.4-37.6\% of energy is used for insect farming, while the bigger part of cumulative energy demand (58.7-79.8\%) is allocated to the production of main consumables (Maiolo et al., 2020). Inclusion of processing in the farming stage rises the impact to 37-55\% of overall energy consumed (Smetana et al., 2019b). Separation of insect rearing and further biomass processing, depending on scenarios, results consumption of $50 \%$ of electricity used for insect rearing (Thévenot et al., 2018). Insect biomass drying is responsible 
for a fraction of 7-45\% of direct electricity used (Bava et al., 2019) and fat separation for around $50 \%$ of electricity used or 48-55\% of cumulative energy demand (Thévenot et al., 2018; Van Zanten et al., 2015). Heating with the gas could add another $22 \%$ to the energy use impact (Van Zanten et al., 2015). Electricity and natural gas use at insect farming then are responsible for $51 \%$ of total GWP (Van Zanten et al., 2015). Similarly, Suckling et al. (2020) indicates the impacts of rearing on global warming to be responsible for $59 \%$ of GWP with third part being allocated to heating. Therefore, the detailed analysis of insect farming and identification of improvement potential could play an important role. Direct metabolic emissions are indicated as neglectable (Ermolaev et al., 2019; Mertenat et al., 2019; Parodi et al., 2020).

\section{Insect cultivation}

The properties of feed for insects to a great degree define the environmental performance of the whole production system due to three main characteristics: (1) type of insect feed and associated upstream impacts; (2) feed conversion ratio; and (3) residual biomass management (Table 2). LCA of insect production therefore should thoroughly, holistically and in a detail define these characteristics. Feed type and composition play an important role due to the upstream environmental impact associated with production (Halloran et al., 2017; Oonincx and De Boer, 2012; Thévenot et al., 2018; Van Zanten et al., 2015) or due to the amount of avoided impacts in case of waste treatment substitution (Bava et al., 2019; Mertenat et al., 2019; Salomone et al., 2017; Smetana, 2020). Feed production for insects is responsible for a vast impact of insect production: $20-99 \%$ of contribution depending on the impact category (Bava et al., 2019; Halloran et al., 2017; Maiolo et al., 2020; Oonincx and De Boer, 2012; Roffeis et al., 2017, 2020; Smetana et al., $2016,2019 b)$. Insect cultivation could be responsible for $95 \%$ of water resource depletion, $70 \%$ of land use, $45 \%$ of ozone depletion, $45 \%$ of freshwater eutrophication (Suckling et al., 2020).

Furthermore, feed conversion (or bioconversion) defines the efficiency of insect feeding and growing, as the lower the feed conversion ratio (FCR) over specific timeframe the higher the performance of the production system and lower the environmental impact as long as the similar impacting feeds are considered. FCR, however, is not always transparently reflected in the studies. Different approaches include 'wet to wet' (Halloran et al., 2017; Maiolo et al., 2020; Oonincx and De Boer, 2012; Van Zanten et al., 2015), 'wet to dry' (Roffeis et al., 2017, 2020; Salomone et al., 2017), 'dry to dry' (Bava et al., 2019; Smetana et al., 2019b) basis. Moreover, in some cases only 'ingested' feed was considered in the analysis of FCR (Bava et al., 2019; Halloran et al., 2017; Oonincx and De Boer, 2012; Thévenot et al., 2018), while other studies include 'non-ingested' feed in the calculations, which jointly with the other factors could result in higher FCR. However, several of the reviewed studies indicate the generation of residual biomass, with further management through by-product allocation (Roffeis et al., 2017, 2020; Smetana et al., 2016, 2019b) or conventional waste treatment through anaerobic digestion (Smetana et al., 2016). Modelling of residual biomass management would therefore include the allocation of part of the total environmental burden to a by-product (lowering the impact of the main insect biomass product) or it will add environmental burden to main product associated with waste treatment.

Energy use, GWP, and water use are the main contributors to the environmental impact of insect cultivation. While data is available from different studies, it is still fragmented, not always transparent and, in many cases, aggregated (thus difficult to reproduce). Data for the insect growing stage are also limited. Some studies indicate on the resources used for insect rearing (Thévenot et al., 2018), climate system (Bava et al., 2019; Smetana et al., 2019b), and insect feeding (Smetana et al., 2016). However, a complete detailed picture is not presented.

\section{Reproduction}

Insect reproduction is included in the production chain as a circulating component, separating a minor part of the adult population for mating and egg laying (Dossey et al., 2016; Ites et al., 2020; Salomone et al., 2017; Thévenot et al., 2018). Most of the studies analyse the larval stage of insect production, as this stage is the most nutritionally relevant for species from Diptera and Coleoptera orders (Table 3). For the Orthoptera order, on the other hand, the adult life stage is relevant, therefore, LCA of such insect production concentrated on adult stages.

Insect reproduction is usually separated from main feeding and growing into a separate facility. Sometimes reproducing population gets another type of treatment, which ensures better reproduction performance. Despite a special treatment, reproduction module is responsible for a minor impact in the scope of 2-8\% (Salomone et al., 2017; Smetana et al., 2019b; Van Zanten et al., 2015), which is often excluded from the boundaries of LCA studies (Ites et al., 2020; Smetana et al., 2016) or combined with main production (Bava et al., 2019; Salomone et al., 2017; Smetana et al., 2019b). In some cases the impact of reproduction can reach up to $10 \%$ (Thévenot et al., 2018). The highest impacts are associated with energy use and global warming potential. Similar to insect growing and feeding, only limited data is available for a transparent analysis. 
Table 2. Insect feeding characteristics. ${ }^{1}$

\begin{tabular}{|c|c|c|c|c|}
\hline Study & Feed type and components & Feed conversion & $\begin{array}{l}\text { Residual biomass } \\
\text { amount }\end{array}$ & $\begin{array}{l}\text { Residual biomass management } \\
\text { modelling }\end{array}$ \\
\hline $\begin{array}{l}\text { Oonincx and De } \\
\text { Boer, } 2012\end{array}$ & $\begin{array}{l}\text { Proprietary feed: fresh carrots, mixed } \\
\text { grains supplemented with beer yeast }\end{array}$ & $\begin{array}{l}2.2 \mathrm{~kg} \text { feed } / \mathrm{kg} \text { live } \\
\text { weight }\end{array}$ & Not provided & $\begin{array}{l}\text { Larvae manure as output, } 100 \% \text { allocation } \\
\text { of impacts to insect output }\end{array}$ \\
\hline Smetana et al., 2015 & $\begin{array}{l}\text { Used data from Oonincx and De Boer } \\
\text { (2012) }\end{array}$ & & & \\
\hline Roffeis et al., 2015 & Pig manure (fresh/dewatered) & $\begin{array}{l}2.8-7.4 \mathrm{~kg} \\
\text { substrate (DM) } \\
\text { for } 0.32-0.35 \mathrm{~kg} \\
\text { insects (DM) }\end{array}$ & $1.8-6.4 \mathrm{~kg}(\mathrm{DM})$ & $\begin{array}{l}\text { Packed residue substrate as one of } \\
\text { outputs of system, all impacts allocated } \\
\text { to FU manure reduction, none to insect } \\
\text { output }\end{array}$ \\
\hline $\begin{array}{l}\text { Van Zanten et al., } \\
2015\end{array}$ & $\begin{array}{l}\text { Mixed: food waste, laying hen } \\
\text { manure, premix (vitamins and } \\
\text { minerals) }\end{array}$ & $\begin{array}{l}4 \mathrm{~kg} \text { substrate } \\
\text { yield } 1 \mathrm{~kg} \text { fresh } \\
\text { larvae }\end{array}$ & Not provided & $\begin{array}{l}\text { Manure considered as fertiliser in } \\
\text { consequential assessment, economic } \\
\text { allocation in attributional part }\end{array}$ \\
\hline $\begin{array}{l}\text { Komakech et al., } \\
2015\end{array}$ & $\begin{array}{l}\text { Organic waste and animal manure } \\
\text { (theoretical) }\end{array}$ & Not provided & Not provided & $\begin{array}{l}\text { Insect frass is a soil improver/fertiliser, } \\
\text { all impacts allocated to use of compost } \\
\text { output; system expansion for (1) avoided } \\
\text { fertiliser production and (2) avoided } \\
\text { production of silver cyprinid for application } \\
\text { in animal feed (fly larvae assumed to } \\
\text { substitute silver cyprinid) }\end{array}$ \\
\hline \multirow[t]{6}{*}{ Smetana et al., 2016} & Grains: rye meal, wheat bran & \multirow{6}{*}{$\begin{array}{l}22-109 \mathrm{~kg} / 1 \mathrm{~kg} \\
\text { of meal and } 0.9 \mathrm{~kg} \\
\text { lipids }\end{array}$} & \multirow[t]{6}{*}{ Not provided } & \multirow{6}{*}{$\begin{array}{l}\text { Insect frass is a fertiliser or treated as } \\
\text { waste, mass and economic allocation }\end{array}$} \\
\hline & Chicken manure & & & \\
\hline & Cattle manure & & & \\
\hline & $\begin{array}{l}\text { Food processing by-product: beet } \\
\text { pulp }\end{array}$ & & & \\
\hline & $\begin{array}{l}\text { Food processing by-product: } \\
\text { distiller's dried grains with solubles } \\
\text { (DDGS) }\end{array}$ & & & \\
\hline & Municipal organic waste & & & \\
\hline Salomone et al., 2017 & $\begin{array}{l}\text { Food waste, average composition: } \\
65 \% \text { vegetal, } 5 \% \text { meat/fish, } 25 \% \\
\text { bread/pasta/rice, } 5 \% \text { other }\end{array}$ & $\begin{array}{l}10 \mathrm{t} \text { feed for } 0.3 \mathrm{t} \\
\text { dried larvae }\end{array}$ & $\begin{array}{l}10 \mathrm{t} \text { feed for } 3.346 \mathrm{t} \\
\text { manure }\end{array}$ & $\begin{array}{l}\text { Larvae frass is a fertiliser, for FU1: system } \\
\text { expansion - avoided compost production; } \\
\text { for FU2, 3: impact of bioconversion fully } \\
\text { allocated to insect output (economic } \\
\text { allocation, lower compost price) }\end{array}$ \\
\hline Halloran et al., 2017 & $\begin{array}{l}\text { Proprietary broiler feed: fish meal, } \\
\text { soybean meal, grain maize, rice bran, } \\
\text { palm oil, calcium carbonate, salt } \\
\text { (optionally pumpkin) }\end{array}$ & $\begin{array}{l}1.47-2.5 \mathrm{~kg} \text { feed } \\
\text { ingested for } 1 \mathrm{~kg} \\
\text { insects (WM) }\end{array}$ & $\begin{array}{l}\text { Quantity of manure } \\
72-85 \% \text { of mass of } \\
\text { harvested crickets } \\
\text { (calculated) }\end{array}$ & $\begin{array}{l}\text { Insect frass is a fertiliser, system } \\
\text { expansion - avoided fertiliser production } \\
\text { (amount based on full substitution of } \mathrm{N}, \mathrm{P} \text {, } \\
\mathrm{K} \text { in residual biomass) }\end{array}$ \\
\hline $\begin{array}{l}\text { Joensuu and } \\
\text { Silvenius, } 2017\end{array}$ & $\begin{array}{l}\text { Used data from Oonincx and De Boer } \\
\text { (2012) and Oonincx et al. (2015) }\end{array}$ & & & \\
\hline Thévenot et al., 2018 & $\begin{array}{l}\text { Composite feed: cereal flours and } \\
\text { meals, wheat bran, beat pulp }\end{array}$ & $\begin{array}{l}1.98 \mathrm{~kg} \text { feed } \\
\text { ingested for } 1 \mathrm{~kg} \\
\text { larvae (WM) }\end{array}$ & $\begin{array}{l}3.85 \mathrm{~kg} \text { per } \mathrm{kg} \text { of } \\
\text { meal }\end{array}$ & $\begin{array}{l}\text { Insect frass is a fertiliser, all impact } \\
\text { allocated to insect outputs; impacts from } \\
\text { fertiliser out of scope }\end{array}$ \\
\hline
\end{tabular}


Table 2. Continued.

\begin{tabular}{|c|c|c|c|c|}
\hline Study & Feed type and components & Feed conversion & $\begin{array}{l}\text { Residual biomass } \\
\text { amount }\end{array}$ & $\begin{array}{l}\text { Residual biomass management } \\
\text { modelling }\end{array}$ \\
\hline \multirow[t]{4}{*}{ Bava et al., 2019} & Control hen diet & $\begin{array}{l}4.22 \mathrm{~kg} \mathrm{DM} \\
\text { ingested feed for } \\
1 \mathrm{~kg} \mathrm{DM} \text { larvae }\end{array}$ & $\begin{array}{l}3.056 \mathrm{~kg} \mathrm{DM} \text { residual } \\
\text { feed and manure }\end{array}$ & \multirow[t]{4}{*}{$\begin{array}{l}\text { Insect frass is a fertiliser, system } \\
\text { expansion - avoided fertiliser production }\end{array}$} \\
\hline & Food processing by-product: okara & $\begin{array}{l}2.80 \mathrm{~kg} \mathrm{DM} \\
\text { ingested feed for } \\
1 \mathrm{~kg} \mathrm{DM} \text { larvae }\end{array}$ & $\begin{array}{l}0.583 \mathrm{~kg} \mathrm{DM} \text { residual } \\
\text { feed and manure }\end{array}$ & \\
\hline & $\begin{array}{l}\text { Food processing by-product: maize } \\
\text { distiller's grains }\end{array}$ & $\begin{array}{l}2.81 \mathrm{~kg} \mathrm{DM} \\
\text { ingested feed for } \\
1 \mathrm{~kg} \mathrm{DM} \text { larvae }\end{array}$ & $\begin{array}{l}2.757 \mathrm{~kg} \mathrm{DM} \text { residual } \\
\text { feed and manure }\end{array}$ & \\
\hline & $\begin{array}{l}\text { Food processing by-product: wet } \\
\text { brewer's spent grains }\end{array}$ & $\begin{array}{l}3.30 \mathrm{~kg} \mathrm{DM} \\
\text { ingested feed for } \\
1 \mathrm{~kg} \mathrm{DM} \text { larvae }\end{array}$ & $\begin{array}{l}0.850 \mathrm{~kg} \mathrm{DM} \text { residual } \\
\text { feed and manure }\end{array}$ & \\
\hline Mertenat et al., 2019 & $\begin{array}{l}\text { Organic waste: segregated } \\
\text { household biowaste }\end{array}$ & Not provided & Not provided & $\begin{array}{l}\text { Residues composted and sold on market; } \\
\text { production of compost is part of functional } \\
\text { unit; impacts allocated to waste treatment } \\
\text { and compost production; system } \\
\text { expansion to substitute larvae meal: } \\
\text { avoided fishmeal production }\end{array}$ \\
\hline \multirow[t]{3}{*}{$\begin{array}{l}\text { Roffeis et al., 2017, } \\
2020\end{array}$} & Chicken manure & $\begin{array}{l}40 \mathrm{~kg} \text { for } 1 \mathrm{~kg} \text { dried } \\
\text { larvae }\end{array}$ & $28 \mathrm{~kg}$ residue & \multirow{3}{*}{$\begin{array}{l}\text { Insect frass is a fertiliser, FU1 system } \\
\text { performance no allocation; FU2 economic } \\
\text { allocation }\end{array}$} \\
\hline & $\begin{array}{l}\text { Sheep manure and fresh ruminant } \\
\text { blood }\end{array}$ & $\begin{array}{l}37 \mathrm{~kg} \text { for } 1 \mathrm{~kg} \text { dried } \\
\text { larvae }\end{array}$ & $16 \mathrm{~kg}$ residue & \\
\hline & $\begin{array}{l}\text { Chicken manure and fresh brewery } \\
\text { waste }\end{array}$ & $\begin{array}{l}15.7 \mathrm{~kg} \text { feed } \\
\text { yielded } 1 \mathrm{~kg} \text { dried } \\
\text { larvae }\end{array}$ & $7.1 \mathrm{~kg}$ residue & \\
\hline Smetana et al., 2019b & $\begin{array}{l}\text { Side streams from milling, alcohol } \\
\text { production, breweries }\end{array}$ & $\begin{array}{l}32.24 \mathrm{~kg} \text { feed } \\
\text { yielded } 1.44 \mathrm{~kg} \\
\text { fresh puree, } \\
1 \mathrm{~kg} \text { meal, } 0.34 \mathrm{~kg} \\
\text { lipids, } 3.82 \mathrm{~kg} \text { frass }\end{array}$ & & $\begin{array}{l}\text { Insect frass is a fertiliser; economic } \\
\text { allocation for outputs (3.08:1 fresh } \\
\text { insects:fertiliser) }\end{array}$ \\
\hline \multirow[t]{3}{*}{ Ites et al., 2020} & Expired food products: organic waste & $\begin{array}{l}10 \mathrm{~kg} \text { for } 1 \text { ton } \\
\text { feed (WM) }\end{array}$ & $60 \mathrm{~kg}$ for 1 ton feed & \multirow[t]{3}{*}{$\begin{array}{l}\text { Insect frass is a fertiliser (hypothetic } \\
\text { economic allocation) }\end{array}$} \\
\hline & $\begin{array}{l}\text { Food processing by-product: potato } \\
\text { peels }\end{array}$ & $\begin{array}{l}0.32 \mathrm{t} \text { insect for } \\
1 \text { ton feed (WM) }\end{array}$ & 0.11 ton for 1 ton feed & \\
\hline & $\begin{array}{l}\text { Food processing by-product: brewery } \\
\text { grains }\end{array}$ & $\begin{array}{l}28.4 \mathrm{~kg} \text { for } 1 \text { ton } \\
\text { feed (WM) }\end{array}$ & 0.12 ton for 1 ton feed & \\
\hline Maiolo et al., 2020 & Cereal by-products/grains & $\begin{array}{l}9.3 \mathrm{t} \text { of feeding } \\
\text { substrate for } \\
1.3 \mathrm{t} \text { larvae (live } \\
\text { weight); } 6 \mathrm{t} \text { of } \\
\text { substrate for } 1 \mathrm{t} \text { of } \\
\text { meal }\end{array}$ & $\begin{array}{l}8,017 \mathrm{~kg} \text { residue } \\
\text { substrate and dead } \\
\text { adult flies per } 1000 \\
\mathrm{~kg} \text { insect meal }\end{array}$ & $\begin{array}{l}\text { Insect frass is a fertiliser, economic } \\
\text { allocation (low value to insect frass) }\end{array}$ \\
\hline Suckling et al., 2020 & $\begin{array}{l}\text { Composite feed: wheat, meals, fats } \\
\text { and oils, additives; plus peat }\end{array}$ & $\begin{array}{l}113.3 \mathrm{t} \text { feeding } \\
\text { substrate (peat } \\
17.46 \mathrm{t} \text { ) for } 12.5 \mathrm{t} \\
\text { crickets (live weight) }\end{array}$ & $\begin{array}{l}107.5 \text { t frass (WM); } \\
98.5 \mathrm{t}(\mathrm{DM})\end{array}$ & $\begin{array}{l}\text { Insect frass is a fertiliser, mass allocation; } \\
\text { avoided production of fertiliser }\end{array}$ \\
\hline
\end{tabular}


Table 3. Insects investigated in life cycle assessment studies.

\begin{tabular}{|c|c|c|c|c|}
\hline Study & Species & Family & Order & Life stage studied \\
\hline $\begin{array}{l}\text { Bava et al., 2019; Bosch et al., 2019; Ites et al., 2020; } \\
\text { Komakech et al., 2015; Maiolo et al., 2020; Roffeis et al., 2017, 2020; } \\
\text { Salomone et al., 2017; Smetana et al., 2016, 2020a }\end{array}$ & Hermetia illucens & Stratiomyidae & Diptera & larval/pre-pupae \\
\hline Mertenat et al., 2019; Smetana et al., 2019b & Hermetia illucens & Stratiomyidae & Diptera & larval/adult \\
\hline $\begin{array}{l}\text { Ites et al., 2020; Joensuu and Silvenius, 2017; } \\
\text { Oonincx and De Boer, 2012; Smetana et al., 2015, 2020a }\end{array}$ & Tenebrio molitor & Tenebrionidae & Coleoptera & larval \\
\hline Thévenot et al., 2018 & Tenebrio molitor & Tenebrionidae & Coleoptera & larval/pre-pupal \\
\hline Oonincx and De Boer, 2012 & Zophobas morio & Tenebrionidae & Coleoptera & larval \\
\hline Van Zanten et al., 2015 & Musca domestica & Muscidae & Diptera & larval \\
\hline Roffeis et al., 2015, 2017, 2020 & Musca domestica & Muscidae & Diptera & larval/adult \\
\hline Ulmer et al., 2020 & Apis mellifera & Apidae & Hymenoptera & pupa \\
\hline Halloran et al., 2017; Suckling et al., 2020 & Gryllus bimaculatus & Gryllidae & Orthoptera & adult \\
\hline Halloran et al., 2017 & Acheta domesticus & Gryllidae & Orthoptera & adult \\
\hline Suckling et al., 2020 & Gryllus sigillatus & Gryllidae & Orthoptera & adult \\
\hline
\end{tabular}

\section{Insect products}

Insect production can result in a few potential products in the range from fresh live insects to fractionated and incorporated intermediates. All these products are a subject for a proper storage to assure their longer preservation and safety of further product development and distribution. These steps are rarely described in LCA studies, with a few exceptions (Smetana et al., 2015, 2020a).

\section{Primary processing}

When insects reach the desired parameters in terms of size, age and composition they are processed in two stages. Primary processing aims to clean insect biomass and eliminate microbial load using operations like sieving, separation, blanching, decontamination or freezing while secondary processing targets improved properties of insect derived components through operations like milling, fractionation via centrifugation, drying and fat separation. The differences in processing result in a variation of end products sold to business or final consumers: whole live insects, whole fresh/frozen insects, fresh insect puree, dried whole larvae, defatted meal, insect oil, intermediate products containing insect components. Variations in processing depths allow to group the scope of most LCA studies into three main system boundaries: (1) cradle-tofarm gate; (2) cradle-to-processing gate; and (3) cradleto-plate (Figure 1). For the first system boundaries (1) the resulting products are alive insects, suitable mostly for feed application (Bosch et al., 2019; Komakech et al., 2015; Oonincx and De Boer, 2012; Suckling et al., 2020). Application of alive larvae for direct food consumption is doubtful as currently there are no companies producing live larvae for direct human consumption. Whole larvae and adult insects, decontaminated and sometimes dried (2), on the other hand, are indicated to be applied directly for food and feed (Bava et al., 2019; Halloran et al., 2017; Ites et al., 2020; Mertenat et al., 2019; Roffeis et al., 2015; Salomone et al., 2017). Most studies, however, are concentrated on the assessment of fractionated or incorporated insect products in cradle-to-processing gate boundaries (Maiolo et al., 2020; Smetana et al., 2016, 2019b, 2020b; Thévenot et al., 2018; Ulmer et al., 2020; Van Zanten et al., 2015).

\section{Storage and packaging}

Storage of insect products is of utmost importance for fresh (high-moisture) products like live, fresh-frozen insects and insect biomass incorporated in high-moisture products (Smetana et al., 2015, 2016; Ulmer et al., 2020). High water activity of such products usually requires low temperatures: cooled conditions for live insects and freezing for other products. Energy consumption in this case might be a considerable factor influencing the environmental impact of the insect product. Therefore, cooling and freezing storage periods should be limited to reduce the environmental impact. Insect based food and feed products of longer shelflife nevertheless require specific storage conditions like dry rooms with climate-controlled conditions. Packaging is rarely mentioned in insect LCA studies and assumed to be comparable to the similar products in feed and food industry. Therefore, it can play a similar role of having a diverse ratio of impacts depending on the size of the product, weight of packaging, and material composition (Vignali, 2016).

\section{Fractionation}

Secondary processing of insect biomass relates to fractionation (separation) into a few fractions: water, lipid and protein. The purity of fractionation depends on the 


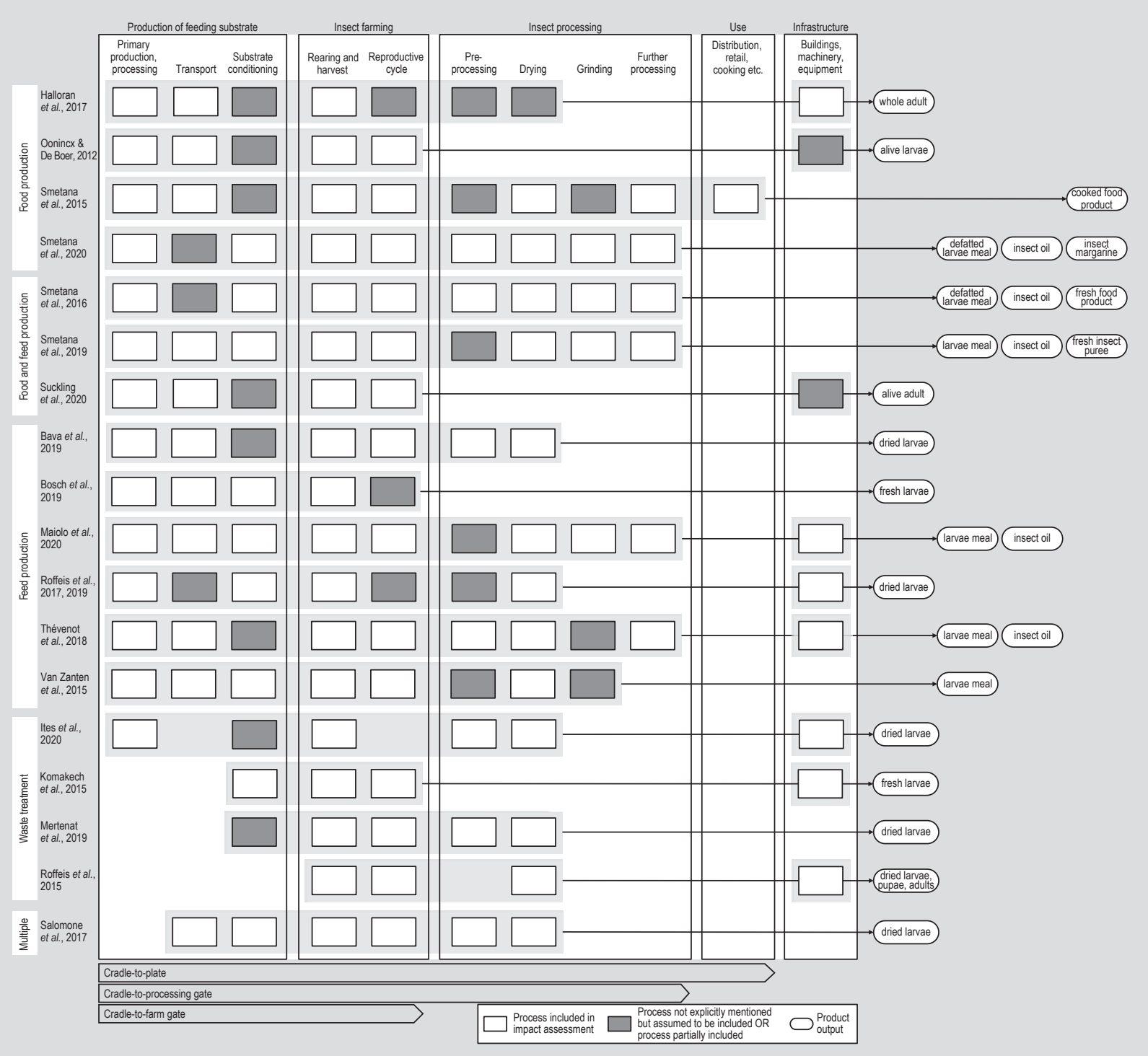

Figure 1. Graphical mapping of insect production chains.

technology applied. Insect drying, relying on different technologies (heat drying, solar drying, freeze-drying) is indicated in a few studies as one of the most common processing techniques used (Bava et al., 2019; Ites et al., 2020; Mertenat et al., 2019; Roffeis et al., 2017, 2020; Salomone et al., 2017; Smetana et al., 2019b). It can have a relatively high energy demand and could results in high associated environmental impacts. In some cases, the heat used for insect production could be sourced as a byproduct from other industries and have low environmental impacts (Joensuu and Silvenius, 2017). In other cases, when a high quality of insect biomass should be assured for food applications, e.g. drying is relying on lyophilisation technologies (freeze-drying of whole larvae (Bava et al., 2019; Lenaerts et al., 2018), which is associated with high energy expenses and relatively high impacts.
Further fractionation techniques include separation of water, lipid and protein fractions from fresh and dry biomass by centrifugation, cold or hot pressing (Alles et al., 2020; Smetana et al., 2019b, 2020a) and in some cases by supercritical liquid extraction (Purschke et al., 2017). Emerging food processing technologies (such as pulsed electric fields) are also finding its niche in improvement of insect biomass fractionation (Alles et al., 2020; Shorstkii et al., 2020; Smetana et al., 2020b). With such developments the dependence on energy is reduced as well as the relative environmental impact.

\section{Integration (product development)}

Further product development is associated with use of the concentrated protein fraction (insect flour, insect meal or defatted protein concentrate) and of insect lipids (fats and 
oils) as a part of a more complex matrix. The applications of both protein and lipid fractions are associated with both feed and pet-food (Gasco et al., 2020; Surendra et al., 2016; Zorrilla and Robin, 2019) as well as food applications (Smetana et al., 2015, 2016, 2018b, 2020a; Tzompa-Sosa et al., 2019). Protein fractions are incorporated into new products through mixing and baking (González et al., 2019; Roncolini et al., 2020); extrusion cooking and pelletising or high-moisture extrusion for meat substitutes production (Smetana et al., 2018b, 2019a; Ulmer et al., 2020). Diverse application possibilities result in several tested and marketed products: pelleted feeds, bars, pasta, spreads, etc. Mixing of fresh or dried insect biomass with plant material results in hybrid products, which potentially can have a lower environmental impact. However, high levels of processing (in case of isolates application) could increase the impacts of the final product.

Lipid fractions are either used as an additive for animal feed (Gasco et al., 2019), for baking purposes (Delicato et al., 2020; Tzompa-Sosa et al., 2019) or as a part of complex fat products such as spreads and margarines (Smetana et al., 2020a). There are only a couple studies, which performed LCA research in the scope of cradle-to-product application boundaries (Figure 1), even though cooking of the product at consumer stage may pose considerable environmental impacts associated with long preservation, excessive wasting and high energy use at inefficient cooking practices (Smetana et al., 2015). Despite multiple challenges associated with suboptimal production chains, insect products are often assessed as having a similar or lower environmental impact compared to conventional food and feed products (Bava et al., 2019; Halloran et al., 2017; Oonincx and De Boer, 2012; Salomone et al., 2017; Smetana et al., 2016, 2020a).

\section{Conceptualisation of a modular assessment framework for insect production}

Despite quite a few studies presenting LCA results, there is an evident lack of systemised information, inhibiting comparisons with other insect products and production chains or with conventional products. Insect production LCA studies are often performed on lab-scale and small pilot-scale level, which does not allow for a direct result transfer to industrial scales (Table 4). Upscaling of insect production will likely decrease the environmental impact of insect product (Heckmann et al., 2019; Smetana et al., 2018a, 2019b).

Climate change is one of the most popular categories of assessment in the studies. Use of a control diet (standard,

Table 4. Characterisation of insect life cycle assessment studies according the production scale and environmental impacts. ${ }^{1}$

\begin{tabular}{|c|c|c|c|c|c|}
\hline \multirow[t]{2}{*}{ Studies } & \multirow[t]{2}{*}{ Unit } & \multirow{2}{*}{$\begin{array}{l}\text { Scale of production/ } \\
\text { assessment }\end{array}$} & \multicolumn{3}{|l|}{ Impacts } \\
\hline & & & Control diet & $\begin{array}{l}\text { Food processing by- } \\
\text { product/food waste }\end{array}$ & Manure diet \\
\hline Bava et al., 2019 & $\begin{array}{l}1 \mathrm{~kg} \text { DM whole } \\
\text { larvae }\end{array}$ & Lab: 1000 larvae per batch & $\begin{array}{l}\text { CC: } 5.76 \\
\text { LU1: } 94.7 \\
\text { WRD: } 1.26\end{array}$ & $\begin{array}{l}\text { CC: } 0.7-2.0 \\
\text { LU1: } 1.3-4.9 \\
\text { WRD: } 0.8-1.1\end{array}$ & $\mathrm{n} / \mathrm{a}$ \\
\hline Bosch et al., 2019 & $1 \mathrm{~kg}$ of protein & $\begin{array}{l}\text { Lab: } 100-1000 \text { larvae per } \\
\text { batch }\end{array}$ & $\begin{array}{l}\text { GWP: } 4-7 \\
\text { EU: } 159-202 \\
\text { LU: } 11-93\end{array}$ & $\begin{array}{l}\text { GWP: } 1-5 \\
\text { EU: } 18-77 \\
\text { LU: } 0-1\end{array}$ & $\begin{array}{l}\text { GWP: } 1-7 \\
\text { EU: } 0-22 \\
\text { LU: } 0\end{array}$ \\
\hline Halloran et al., 2017 & $\begin{array}{l}\text { FU1: } 1 \mathrm{~kg} \text { edible } \\
\text { WW; } \\
\text { FU2: } 1 \mathrm{~kg} \text { of protein } \\
\text { in edible }\end{array}$ & $\begin{array}{l}\text { Pilot: } 36.7 \text { tons of insects } \\
\text { annually }\end{array}$ & $\begin{array}{l}\text { FU } 1 \\
\text { CC: } 2.3-2.6 \\
\text { WRD: } 0.42 \\
\text { FU } 2 \\
\text { CC: } 3.9-4.4 \\
\text { WRD: } 0.71\end{array}$ & $\mathrm{n} / \mathrm{a}$ & $\mathrm{n} / \mathrm{a}$ \\
\hline $\begin{array}{l}\text { Joensuu and Silvenius, } \\
2017\end{array}$ & $\begin{array}{l}\text { FU1: } 1 \mathrm{~kg} \text { WM whole } \\
\text { larvae; } \\
\text { FU2: } 1 \mathrm{~kg} \text { of protein }\end{array}$ & $\begin{array}{l}\text { Based on: } \\
\text { Oonincx et al., 2015; } \\
\text { Oonincx and de Boer, } 2012\end{array}$ & $\begin{array}{l}\text { FU1: } \\
\text { GWP2: } 3.1 \\
\text { FU2: } \\
\text { GWP2: 23-27 }\end{array}$ & $\begin{array}{l}\text { FU1: } \\
\text { GWP2: } 3.1\end{array}$ & $\mathrm{n} / \mathrm{a}$ \\
\hline Ites et al., 2020 & $\begin{array}{l}1 \mathrm{~kg} \text { DM whole } \\
\text { larvae* }\end{array}$ & $\begin{array}{l}\text { Pilot mobile: } 12.7-64 \text { tons } \\
\text { of insects annually }\end{array}$ & $\mathrm{n} / \mathrm{a}$ & $\begin{array}{l}\text { GWP1: }-6.42 \text { to } 2.0 \\
\text { NRE: }-108 \text { to } 8.9 \\
\text { LO: }-16.8 \text { to }-0.006\end{array}$ & $\mathrm{n} / \mathrm{a}$ \\
\hline
\end{tabular}


Table 4. Continued.

\begin{tabular}{|c|c|c|c|c|c|}
\hline \multirow[t]{2}{*}{ Studies } & \multirow[t]{2}{*}{ Unit } & \multirow{2}{*}{$\begin{array}{l}\text { Scale of production/ } \\
\text { assessment }\end{array}$} & \multicolumn{3}{|l|}{ Impacts } \\
\hline & & & Control diet & $\begin{array}{l}\text { Food processing by- } \\
\text { product/food waste }\end{array}$ & Manure diet \\
\hline Komakech et al., 2015 & $\begin{array}{l}1 \mathrm{~kg} \text { DM whole } \\
\text { larvae* }^{*}\end{array}$ & $\begin{array}{l}\text { Industrial hypothetical: } \\
426 \text { tons of insects annually }\end{array}$ & $\mathrm{n} / \mathrm{a}$ & $\begin{array}{l}\text { GWP2: } 0.29 \\
\text { EU1: } 0.36\end{array}$ & $\mathrm{n} / \mathrm{a}$ \\
\hline $\begin{array}{l}\text { Oonincx and De Boer, } \\
2012\end{array}$ & $\begin{array}{l}1 \mathrm{~kg} \mathrm{WM} \text { whole } \\
\text { larvae }\end{array}$ & $\begin{array}{l}\text { Pilot: } 83 \text { tons of fresh } \\
\text { insects annually }\end{array}$ & $\begin{array}{l}\text { GWP2: } 2.7 \\
\text { EU1: } 33.7 \\
\text { LU: } 3.6\end{array}$ & $\mathrm{n} / \mathrm{a}$ & $\mathrm{n} / \mathrm{a}$ \\
\hline Roffeis et al., 2015 & $\begin{array}{l}1 \mathrm{~kg} \mathrm{DM} \text { whole } \\
\text { larvae* }^{*}\end{array}$ & $\begin{array}{l}\text { Pilot: } \\
1 \text { tonne manure per week }\end{array}$ & $\mathrm{n} / \mathrm{a}$ & $\mathrm{n} / \mathrm{a}$ & $\begin{array}{l}\text { FD: } 5.9-9.7 \\
\text { ALO: } 4.4-7.7 \\
\text { WD: } 113.9-187.6\end{array}$ \\
\hline $\begin{array}{l}\text { Roffeis et al., 2017, } \\
2020\end{array}$ & $\begin{array}{l}1 \mathrm{~kg} \mathrm{DM} \text { whole } \\
\text { larvae }\end{array}$ & $\begin{array}{l}\text { Pilot: } \\
\text { 3.5-4.4 tons DM larvae } \\
\text { annually }\end{array}$ & $\mathrm{n} / \mathrm{a}$ & $\begin{array}{l}\text { GWP3: 4.5-12; } \\
\text { FD: } 0.96-1.5 \\
\text { ALO: } 5.5-61 \\
\text { WD: } 8.5-11\end{array}$ & \\
\hline Salomone et al., 2017 & $\begin{array}{l}1 \mathrm{~kg} \mathrm{DM} \text { whole } \\
\text { larvae* }^{*}\end{array}$ & $\begin{array}{l}\text { Pilot industrial: } \\
110-329 \text { tons DM larvae } \\
\text { annually }\end{array}$ & $\mathrm{n} / \mathrm{a}$ & $\begin{array}{l}\text { GWP4: } 1.0 \\
\text { EU2: } 7.2 \\
\text { LU3: } 0.022\end{array}$ & $\mathrm{n} / \mathrm{a}$ \\
\hline Smetana et al., 2016 & $\begin{array}{l}1 \mathrm{~kg} \mathrm{DM} \text { dried } \\
\text { defatted powder }\end{array}$ & $\begin{array}{l}\text { Pilot industrial: } 50 \text { tons } \\
\text { insect flour }\end{array}$ & $\begin{array}{l}\text { GWP1,3: 1.36-15.1 } \\
\text { NRE: } 21.2-99.6 \\
\text { (A)LO: 0.0032-7.03 }\end{array}$ & & \\
\hline Smetana et al., 2019b & $1 \mathrm{~kg}$ DM dried meal & $\begin{array}{l}\text { Industrial: more than } 1000 \\
\text { tons DM larvae annually }\end{array}$ & $\mathrm{n} / \mathrm{a}$ & $\begin{array}{l}\text { GWP1: } 5.3 \\
\text { NRE: } 84.2 \\
\text { LO: } 1.9 \\
\text { WU: } 2.8\end{array}$ & $\mathrm{n} / \mathrm{a}$ \\
\hline Smetana et al., 2020a & $\begin{array}{l}1 \text { kg DM margarine } \\
\text { (insect lipids) }\end{array}$ & $\begin{array}{l}\text { Based on: } \\
\text { Smetana et al., 2019b; } \\
\text { Thévenot et al., } 2018\end{array}$ & $\mathrm{n} / \mathrm{a}$ & $\begin{array}{l}\text { GWP1:2.4-4.1 } \\
\text { NRE: } 16.4-54 \\
\text { LO: } 2.4-3.7\end{array}$ & $\mathrm{n} / \mathrm{a}$ \\
\hline Thévenot et al., 2018 & $\begin{array}{l}1 \mathrm{~kg} \text { WM whole } \\
\text { larvae }\end{array}$ & $\begin{array}{l}\text { Pilot: } 17 \text { t WM larvae } \\
\text { annually }\end{array}$ & $\mathrm{n} / \mathrm{a}$ & $\begin{array}{l}\text { EU2: } 24.3 \\
\text { CC1: } 0.99 \\
\text { LU3: } 1.6\end{array}$ & $\mathrm{n} / \mathrm{a}$ \\
\hline Ulmer et al., 2020 & $1 \mathrm{~kg}$ of edible protein & $\begin{array}{l}\text { Lab: } 40 \mathrm{~kg} \text { WM from } \\
12 \text { colonies annually }\end{array}$ & $\begin{array}{l}\text { GWP1: } 15-29 \\
\text { NRE: } 248-425 \\
\text { LO: } 1.1-17\end{array}$ & $\mathrm{n} / \mathrm{a}$ & $\mathrm{n} / \mathrm{a}$ \\
\hline Van Zanten et al., 2015 & $1 \mathrm{~kg} \mathrm{DM}$ dried meal & Pilot industrial? & $\mathrm{n} / \mathrm{a}$ & $\begin{array}{l}\text { GWP2: } 0.77 \\
\text { EU1: } 9.3 \\
\text { LU2: } 0.032\end{array}$ & \\
\hline Suckling et al., 2020 & $\begin{array}{l}1 \mathrm{~kg} \text { WM whole } \\
\text { larvae }\end{array}$ & $\begin{array}{l}\text { Pilot: } 12.5 \text { t WM insects } \\
\text { annually }\end{array}$ & $\begin{array}{l}\text { CC: } 21.1 \\
\text { LU1: } 157 \\
\text { WRD: } 0.82\end{array}$ & $\mathrm{n} / \mathrm{a}$ & \\
\hline $\begin{array}{l}{ }^{1} \mathrm{ALO}=\text { agricultural lanc } \\
\mathrm{DM}=\text { dry matter basis; } \\
\mathrm{FD}=\text { fossil depletion } \mathrm{kg} \\
\mathrm{kg} \mathrm{CO}{ }_{2} \text { eq. (IMPACT2OC } \\
\mathrm{CO}_{2} \text { eq. (ReCiPe); GWF } \\
\mathrm{m}^{2} \text { (not specified metho } \\
=\text { non-renewable energy } \\
\text { resource depletion in } \mathrm{m}\end{array}$ & $\begin{array}{l}\text { occupation in m²yr (Re } \\
\text { U = energy use in MJ ( } \\
\text { oil eq. (ReCiPe); GWP } \\
\text { 2+); GWP2 = global wa } \\
4 \text { = global warming pot } \\
\text { d); LU1 = land use in kg } \\
\text { consumption in MJ prir } \\
\text { water eq. (ILCD 2011); }\end{array}$ & $\begin{array}{l}\text { eCiPe); } \mathrm{CC} 1 \text { = climate change } \\
\text { (not specified method); EU1 = } \\
=\text { global warming potential in } \mathrm{k} \\
\text { arming potential } 100 \text { years in } \mathrm{k} \\
\text { ential in kg } \mathrm{CO}_{2} \text { eq. (IPCC } 200 \\
\mathrm{C} \text { deficit (ILCD 2011); LU2 = } \\
\text { mary (IMPACT2002+); WD = } \\
\text {; WU = water use in L deprived }\end{array}$ & $\begin{array}{l}\text { in } \mathrm{kg} \mathrm{CO}_{2} \text { eq. (CML2) } \\
\text { energy use in MJ (sep } \\
\mathrm{g} \mathrm{CO}_{2} \text { eq. (not specifi } \\
\mathrm{g} \mathrm{CO}_{2} \text { eq. (separate ir } \\
\text { J); } \mathrm{LO}=\text { land occupa } \\
\text { land use in } \mathrm{m}^{2} \text {, separa } \\
\text { vater depletion in } \mathrm{m}^{3} \text { ( } \\
\text { (IMPACT World }+)^{*}\end{array}$ & $\begin{array}{l}C C=\text { climate change in k } \\
\text { arate indicator); EU2 = en } \\
\text { d method); GWP1 = glob } \\
\text { dicator); GWP3 = global v } \\
\text { on } \mathrm{m}^{2} \text { org arable (IMPAC } \\
\text { e indicator; LU3 = land us } \\
\text { eCiPe); WM = wet matte } \\
\text { recalculated for } 1 \mathrm{~kg} \mathrm{DM}\end{array}$ & $\begin{array}{l}\mathrm{CO}_{2} \text { eq. (ILCD 2011); } \\
\text { y use in MJ (CML 2); } \\
\text { warming potential in } \\
\text { ming potential in kg } \\
002+\text { ); LU = land use } \\
\text { in }^{2} \text { a (CML 2); NRE } \\
\text { asis; WRD = water } \\
\text { whole larvae. }\end{array}$ \\
\hline
\end{tabular}


based on commercial or proprietary feed) is associated in with 2.3-3.1 $\mathrm{kg} \mathrm{CO}$ eq. per $\mathrm{kg}$ of fresh insects produced (Halloran et al., 2017; Joensuu and Silvenius, 2017; Oonincx and De Boer, 2012). It corresponds well to the results presented for $1 \mathrm{~kg}$ of dried larvae: $5.76 \mathrm{~kg} \mathrm{CO}$ eq. (Bava et al., 2019) and for $1 \mathrm{~kg}$ of protein: $3.9-7 \mathrm{~kg} \mathrm{CO}_{2}$ eq. (Bosch et al., 2019; Halloran et al., 2017). At the same time, some authors highlight carbon footprint as high as $21.1 \mathrm{~kg} \mathrm{CO}_{2}$ eq. per $\mathrm{kg}$ of fresh larvae (Suckling et al., 2020) or in the range of $15-29 \mathrm{~kg} \mathrm{CO}_{2}$ eq. per $\mathrm{kg}$ of protein (Ulmer et al., 2020). The high impact in last studies is explained by inclusion of frass application to the field as emission factor (Suckling et al., 2020) or by the analysis of a very different production system with low technology readiness level (Ulmer et al., 2020).

Global warming potential impacts of insect production based on food processing by-products (food waste) can vary in a wide range from positive for the environment -6.42 to $5.3 \mathrm{~kg} \mathrm{CO}_{2}$ eq. for all the FUs (Bava et al., 2019; Bosch et al., 2019; Ites et al., 2020; Joensuu and Silvenius, 2017; Komakech et al., 2015; Salomone et al., 2017; Smetana et al., 2019b; Thévenot et al., 2018; Van Zanten et al., 2015). The only study differentiated form the majority indicates somewhat higher impacts of 4.5-12 $\mathrm{kg} \mathrm{CO}_{2}$ eq. per $1 \mathrm{~kg}$ DM (Roffeis et al., 2017, 2020). Application of manure as feed for insects could have a great potential for the environmental improvement (Smetana et al., 2016). However, reviewed studies indicated considerable impacts on the environment from 0.77-12 $\mathrm{kg} \mathrm{CO}_{2}$ eq. per $1 \mathrm{~kg}$ of dried insects (Roffeis et al., 2017, 2020) to $1-7 \mathrm{~kg} \mathrm{CO}_{2}$ eq. per $1 \mathrm{~kg}$ of proteins (Bosch et al., 2019).

Water footprint is assessed only in a few studies, indicating that with control diet $1 \mathrm{~kg}$ of fresh insects result in 0.42-0.82 $\mathrm{m}^{3}$ of water depleted (Halloran et al., 2017; Suckling et al., 2020). Similar impact is indicated for the protein-based unit: $0.71 \mathrm{~m}^{3}$ (Halloran et al., 2017). Calculation of the results per dry matter content results in higher impacts $1.26 \mathrm{~m}^{3}$ (Bava et al., 2019).

Production of insects on by-products (food waste) results in the contradictory amounts of water depleted from low 0.8-1.1 $\mathrm{m}^{3}$ per $\mathrm{kg}$ of dry matter content (Bava et al., 2019) to high $8.5-11 \mathrm{~m}^{3}$ per $\mathrm{kg}$ of fresh insects produced (Roffeis et al., 2017, 2020). Water footprint of insects produced on manure is also not indicative with ranges from low: 8.5-11 $\mathrm{m}^{3}$ per $1 \mathrm{~kg}$ of insect on dry matter basis (Roffeis et al., 2017, 2020) to very high: 113.9-187.6 $\mathrm{m}^{3}$ (Roffeis et al., 2015). There is a lack of studies indicating the water footprint of insects grown on food waste and manure. Higher impacts might be explained by more regionalised approach taken in the studies (Roffeis et al., 2015, 2017, 2020).

Application of conventional diet results in quite high energy use impacts: $33.7 \mathrm{MJ}$ per $\mathrm{kg}$ of fresh insects produced
(Oonincx and De Boer, 2012); 159-425 MJ for $1 \mathrm{~kg}$ of proteins (Bosch et al., 2019; Ulmer et al., 2020). Energy use for insect production in case they are grown on byproducts and food waste according to the reviewed studies is very diverse and ranges from rather positive -108 to $8.9 \mathrm{MJ}$ per $1 \mathrm{~kg}$ of insect biomass on dry matter basis (Ites et al., 2020; Komakech et al., 2015; Salomone et al., 2017) to high impacts of $24.3 \mathrm{MJ}$ per $\mathrm{kg}$ of fresh insects produced (Thévenot et al., 2018) or 18-77 MJ per $1 \mathrm{~kg}$ protein (Bosch et al., 2019). Variations in the impacts can be explained by the differences in the modelling approaches (consideration of raw materials as by-products or wastes).

Use of energy for insect production on manure highlighted in a few studies, has moderate ranges: from 9.3-62.8 MJ per $1 \mathrm{~kg}$ of dry insects (Roffeis et al., 2017, 2020; Van Zanten et al., 2015) and 0-22 MJ per $1 \mathrm{~kg}$ of proteins (Bosch et al., 2019). However, a single study indicated a huge potential impact in energy use: 247-406 MJ per $1 \mathrm{~kg}$ of dry larvae (Roffeis et al., 2015). The explanation might lay in the biological or geographical variations applied in the study.

Assessment of land use impact in the studies dealing with conventional diet is not straightforward. While production of fresh insects could result in $3.6 \mathrm{~m}^{2}$ per $\mathrm{kg}$ of fresh insects produced (Oonincx and de Boer, 2012), land use impact calculated in other studies is much higher: $94.7 \mathrm{~m}^{2}$ per 1 $\mathrm{kg}$ of insects dry matter basis (Bava et al., 2019), 1.1-93 $\mathrm{m}^{2}$ per $1 \mathrm{~kg}$ of proteins (Bosch et al., 2019; Ulmer et al., 2020). Land use impacts of insect production of by-products are indicated as low: $1.6 \mathrm{~m}^{2}$ per $\mathrm{kg}$ of fresh insects produced (Thévenot et al., 2018); -16.8 to $4.9 \mathrm{~m}^{2}$ per $1 \mathrm{~kg}$ of insect on a dry matter basis (Bava et al., 2019; Ites et al., 2020; Salomone et al., 2017; Smetana et al., 2019b; Van Zanten et al., 2015) and 0-1 $\mathrm{m}^{2}$ per $1 \mathrm{~kg}$ proteins (Bosch et al., 2019). Studies of Roffeis et al. $(2017,2020)$ highlight the possibility of higher land use impact: $5.5-61 \mathrm{~m}^{2}$ per $1 \mathrm{~kg}$ on dry matter basis. Regionality might play here a high role as well. Land use impacts were low in studies dealing with manure treatment: $0.032-7.7 \mathrm{~m}^{2}$ per $1 \mathrm{~kg}$ of insect on dry matter basis (Roffeis et al., 2015; Van Zanten et al., 2015) and even neutral in some cases: $0 \mathrm{~m}^{2}$ per $1 \mathrm{~kg}$ of proteins (Bosch et al., 2019). And again, there was one outline study highlighting rather high impact associated with land use: $5.5-61 \mathrm{~m}^{2}$ per $1 \mathrm{~kg}$ of insects produced (Roffeis et al., 2015) potentially due to its concentration on a specific regional basis.

The variations in insect species, units of measurement, assessed scale of production and feeding diets do not allow for a straightforward evaluation of different production pathways (Table 4). However, the overall tendency indicates that the use of food processing by-products, wastes or manure for insect feeding can reduce the environmental impact of insect products (Bosch et al., 2019; Ites et al., 2020; Komakech et al., 2015; Roffeis et al., 2017, 2020; 
Salomone et al., 2017; Smetana et al., 2016; Van Zanten et al., 2015). The impact of insect production furthermore can be reduced through the application of alternative energy sources (Smetana et al., 2016, 2019b), use of insect for additional ecosystem services tasks (pollination, biotransformation) (Ulmer et al., 2020), application of more efficient processing chains and use of passive heating and cooling methods or application of live insect with minimal processing.

The complexity of insect production chains does not allow for simple and straightforward answers about the environmental impact of insect-based products. The impact depends on the type of insect, compositions of the diet, optimisation of growing conditions, level of processing, type of distribution, etc. In order to analyse the relative efficiency, economic feasibility and environmental impact of insect production chains it is necessary to rely on a systematic holistic approach, which should include modularisation of insect production stages and their analysis on a standardised scale.

Based on the reviewed publications and available results of LCA studies we propose a modular framework, which should improve the performance of future LCA studies. It consists of 3 main components. The first component includes determination of system boundaries of insect production chains and relevant comparable studies via graphical mapping (Figure 1). For a comparative analysis insect production chains should be divided conceptually into five main groups representing: (1) the production of feeding substrate (as indicated to be of highest importance for the environmental impact); (2) insect farming; (3) processing; (4) overall infrastructure; and (5) application of insect product. These five groups combine represent the variability in the scope and boundaries of LCA - cradle-to-gate, cradle-to-plate, etc. (Figure 1), which leads to the identification of the type of insect production chain. Further LCA analysis should include more detailed modules of insect production. For example, insect farming could be further differentiated into modules of reproduction, fattening, supporting services (washing), and pre-processing (if located in the same facility). Thus, the characterisation of substrate production should include primary production or processing, transportation and on-site substrate conditioning. Insect farming consists of two main modules: rearing-harvesting and reproduction. Insect processing includes pre-processing, fractionation, grinding, and secondary processing for product development. The use phase should include distribution, retail, cooking and utilisation. Infrastructure consists of buildings, machinery and equipment relevant to capital investments. Such modular conceptualisation of LCA approaches to insect production chains allows to systematically consider the most important components and parameters relevant for a reliable analysis, determine the proper FU, scale of production and impact assessment methodology.

The second component of the framework should include the modularisation of insect production chain according to the modularisation scheme (Figure 1) and LCIA approaches (Table 1). Determination of modules should allow for the identification of important production chain elements and relevant data required. Moreover, setting up the analysis based on proposed modules should support the balance model thinking crucial for the correct results in LCA. Identification of relevant LCIA methodology should eliminate further hurdles of results interpretation and comparability with other studies.

The third component of modular framework includes the consideration of a FU and production scale (Table 4). Changes in both these parameters can affect the results and alter the final outcomes and conclusions. Such an approach provides a justified and solid basis for conducting stateof-the-art LCA and enables a reliable comparison of LCA studies of different insect production chains.

The proposed approach has certain limitations. First, it is based on the standardised approach to the LCA, which currently does not include the impact on biodiversity. There are a few methods being developed, which can find the application and can be also accounted in insect production LCA studies. Another indirect aspect which can be considered in the future is the direct potential impact of insect production especially dealing with waste treatment on the health of workers. Potential negative consequences might include allergies or intoxications. Currently there is not enough information on the potential effects, especially if the safety measures are considered. In future studies such information should be included. Animal welfare of insect production could also be a potential assessment category included in future LCA studies.

\section{Conclusions}

The study was oriented to review current scientific literature to establish a modular framework for the determination of environmental contribution of different parts of insect production chains.

Most LCA studies concentrated on attributional approach with results presented for several impact categories. Analysed studies relied on diverse impact assessment methods (LCIA) which can be grouped into ReCiPe, IMPACT 2002+, CML, ILCD and separate indicators. The goal of reviewed LCA articles deals with estimation of environmental impact of insect production for food and feed purposes to waste and manure treatment scenarios. Most studies rely on primary data from pilot insect production or on mix of primary data and information from 
the literature. There is a lack of studies, which would include the transportation and distribution of insect biomass/ products, as most studies concentrate on cradle-to-gate approach.

The studies also reflected on environmental hot spots, which included production of feed (in case of commercial feed), insect cultivation and processing. Most impacts are associated with use of energy (electricity, fuel, natural gas). These factors are associated with high impacts in categories of global warming potential, non-renewable energy use, water and land use. Type of feed and modelling of its assessment was in many cases decisive for the determination of environmental impact of insects. Selection of by-product allocation rules, substitution criteria and waste scenarios determined the wide ranges of environmental impacts presented for food processing by-products, food waste and manure. Most LCA studies concentrated production of three insect species: Hermetia illucens, Tenebrio molitor and Musca domestica. Other five species are covered by single studies.

The analysis indicated that research literature is very diverse in the scope and boundaries of the LCA, selection of FU, LCIA methodologies, assessed insect species, scale of production and other aspects. For performing further LCA studies a systemised modular approach was suggested. It consists of three stages: (1) determination of system boundaries of insect production chains and relevant comparable studies via graphical mapping; (2) the modularisation of insect production chain according to the modularisation scheme and LCIA approaches; (3) the consideration of a FU and production scale which may affect the results and alter the final outcomes and conclusions.

\section{Acknowledgements}

Research is partially supported by the German Federal Ministry of Education and Research (BMBF), grant number 01DN17017 through Era-Net LAC project EntoWaste (ELAC2015/T03-0580), grant number 031B0934A through FACCE-SURPLUS project UpWaste, and partially by the European Union's Horizon 2020 research and innovation programme under grant agreement no. 861976 project SUSINCHAIN.

\section{Conflict of interest}

The authors declare no conflict of interest.

\section{References}

Alexandratos, N. and Bruinsma, J., 2012. World agriculture towards 2030/2050: the 2012 revision. FAO, Rome, Italy. Available at: http:// www.fao.org/3/a-ap106e.pdf.
Allegretti, G., Talamini, E., Schmidt, V., Bogorni, P.C. and Ortega, E., 2018. Insect as feed: an emergy assessment of insect meal as a sustainable protein source for the Brazilian poultry industry. Journal of Cleaner Production 171: 403-412.

Alles, M.C., Smetana, S., Parniakov, O., Shorstkii, I., Toepfl, S., Aganovic, K. and Heinz, V., 2020. Bio-refinery of insects with pulsed electric field pre-treatment. Innovative Food Science \& Emerging Technologies 64: 102403.

Allio, L., 2007. Better regulation and impact assessment in the European Commission. Regulatory impact assessment: towards better regulation. EC, Brussels, Belgium, pp. 72-105.

Ardente, F. and Cellura, M., 2012. Economic allocation in life cycle assessment: the state of the art and discussion of examples. Journal of Industrial Ecology 16: 387-398.

Bach, V., Lehmann, A., Görmer, M. and Finkbeiner, M., 2018. Product environmental footprint (PEF) pilot phase - comparability over flexibility? Sustainability 10: 2898.

Bava, L., Jucker, C., Gislon, G., Lupi, D., Savoldelli, S., Zucali, M. and Colombini, S., 2019. Rearing of Hermetia Illucens on different organic by-products: influence on growth, waste reduction, and environmental impact. Animals 9: 289.

Bosch, G., Van Zanten, H.H.E., Zamprogna, A., Veenenbos, M., Meijer, N.P., Van der Fels-Klerx, H.J. and Van Loon, J.J.A., 2019. Conversion of organic resources by black soldier fly larvae: legislation, efficiency and environmental impact. Journal of Cleaner Production 222: 355-363.

Buyle, M., Audenaert, A., Billen, P., Boonen, K. and Van Passel, S., 2019. The future of ex-ante LCA? Lessons learned and practical recommendations. Sustainability 11: 5456.

Cucurachi, S., Scherer, L., Guinée, J. and Tukker, A., 2019. Life cycle assessment of food systems. One Earth 1: 292-297.

Cucurachi, S., Van der Giesen, C. and Guinée, J., 2018. Ex-ante LCA of emerging technologies. Procedia CIRP 69: 463-468.

Del Borghi, A., 2013. LCA and communication: environmental product declaration. The International Journal of Life Cycle Assessment 18: 293-295.

Delicato, C., Schouteten, J.J., Dewettinck, K., Gellynck, X. and TzompaSosa, D.A., 2020. Consumers' perception of bakery products with insect fat as partial butter replacement. Food Quality and Preference 79: 103755.

Dossey, A.T., Tatum, J.T. and McGill, W.L., 2016. Modern insect-based food industry: current status, insect processing technology, and recommendations moving forward. Insects as Sustainable Food Ingredients. Elsevier, Amsterdam, the Netherlands, pp. 113-152.

Ermolaev, E., Lalander, C. and Vinnerås, B., 2019. Greenhouse gas emissions from small-scale fly larvae composting with Hermetia illucens. Waste Management 96: 65-74.

Fava, J.A., 1993. Life cycle thinking: application to product design. Proceedings of the 1993 IEEE International Symposium on Electronics and the Environment. May 10-12, 1993. Arlington, VI, USA, pp. 69-73.

Fukushima, Y. and Hirao, M., 2002. A structured framework and language for scenario-based life cycle assessment. The International Journal of Life Cycle Assessment 7: 317. 
Gasco, L., Biancarosa, I. and Liland, N.S., 2020. From waste to feed: a review of recent knowledge on insects as producers of protein and fat for animal feeds. Current Opinion in Green and Sustainable Chemistry 23: 67-79. https://doi.org/10.1016/j.cogsc.2020.03.003

Gasco, L., Dabbou, S., Trocino, A., Xiccato, G., Capucchio, M.T., Biasato, I., Dezzutto, D., Birolo, M., Meneguz, M., Schiavone, A. and Gai, F., 2019. Effect of dietary supplementation with insect fats on growth performance, digestive efficiency and health of rabbits. Journal of Animal Science and Biotechnology 10: 4.

Gold, M., Cassar, C.M., Zurbrügg, C., Kreuzer, M., Boulos, S., Diener, S. and Mathys, A., 2020. Biowaste treatment with black soldier fly larvae: Increasing performance through the formulation of biowastes based on protein and carbohydrates. Waste Management 102: 319-329.

González, C.M., Garzón, R. and Rosell, C.M., 2019. Insects as ingredients for bakery goods. A comparison study of H. illucens, A. domestica and T. molitor flours. Innovative Food Science \& Emerging Technologies 51: 205-210.

Gouel, C. and Guimbard, H., 2019. Nutrition transition and the structure of global food demand. American Journal of Agricultural Economics 101: 383-403.

Guinée, J.B., Cucurachi, S., Henriksson, P.J.G. and Heijungs, R., 2018. Digesting the alphabet soup of LCA. The International Journal of Life Cycle Assessment 23: 1507-1511.

Halloran, A., Hanboonsong, Y., Roos, N. and Bruun, S., 2017. Life cycle assessment of cricket farming in north-eastern Thailand. Journal of Cleaner Production 156: 83-94.

Heckmann, L.-H., Andersen, J.L., Eilenberg, J., Fynbo, J., Miklos, R., Jensen, A.N., Nørgaard, J.V. and Roos, N., 2019. A case report on inVALUABLE: insect value chain in a circular bioeconomy. Journal of Insects as Food and Feed 5: 9-13. https://doi.org/10.3920/ JIFF2018.0009

Hertwich, E.G., 2008. Consumption and the rebound effect: an industrial ecology perspective. Journal of Industrial Ecology 9: 85-98.

Isibika, A., Vinnerås, B., Kibazohi, O., Zurbrügg, C. and Lalander, C., 2019. Pre-treatment of banana peel to improve composting by black soldier fly (Hermetia illucens (L.), Diptera: Stratiomyidae) larvae. Waste Management 100: 151-160.

International Organization for Standardization (ISO), 2006a. ISO 14040 Environmental management - life cycle assessment principles and framework. ISO, Geneva, Switzerland.

International Organization for Standardization (ISO), 2006b. ISO 14044 Environmental management - life cycle assessment requirements and guidelines. ISO, Geneva, Switzerland.

Ites, S., Smetana, S., Toepfl, S. and Heinz, V., 2020. Modularity of insect production and processing as a path to efficient and sustainable food waste treatment. Journal of Cleaner Production 248: 119248.

Joensuu, K. and Silvenius, F., 2017. Production of mealworms for human consumption in Finland: a preliminary life cycle assessment. Journal of Insects as Food and Feed 3: 211-216. https://doi. org/10.3920/JIFF2016.0029

Jungbluth, N., Tietje, O. and Scholz, R.W., 2000. Food purchases: impacts from the consumers' point of view investigated with a modular LCA. The International Journal of Life Cycle Assessment 5: $134-142$.
Komakech, A.J., Sundberg, C., Jönsson, H. and Vinnerås, B., 2015. Life cycle assessment of biodegradable waste treatment systems for sub-Saharan African cities. Resources, Conservation and Recycling 99: 100-110.

Lenaerts, S., Van Der Borght, M., Callens, A. and Van Campenhout, L., 2018. Suitability of microwave drying for mealworms (Tenebrio molitor) as alternative to freeze drying: impact on nutritional quality and colour. Food Chemistry 254: 129-136.

Maiolo, S., Parisi, G., Biondi, N., Lunelli, F., Tibaldi, E. and Pastres, R., 2020. Fishmeal partial substitution within aquafeed formulations: life cycle assessment of four alternative protein sources. The International Journal of Life Cycle Assessment 25: 1455-1471.

McAuliffe, G.A., Chapman, D.V. and Sage, C.L., 2016. A thematic review of life cycle assessment (LCA) applied to pig production. Environmental Impact Assessment Review 56: 12-22.

Mertenat, A., Diener, S. and Zurbrügg, C., 2019. Black soldier fly biowaste treatment - assessment of global warming potential. Waste Management 84: 173-181.

Mondello, G., Salomone, R., Ioppolo, G., Saija, G., Sparacia, S. and Lucchetti, M., 2017. Comparative LCA of alternative scenarios for waste treatment: the case of food waste production by the massretail sector. Sustainability 9: 827.

Mont, O. and Bleischwitz, R., 2007. Sustainable consumption and resource management in the light of life cycle thinking. European Environment 17: 59-76.

Oonincx, D.G.A.B. and De Boer, I.J.M., 2012. Environmental impact of the production of mealworms as a protein source for humans - a life cycle assessment. PLoS ONE 7: e51145.

Oonincx, D.G.A.B., Van Broekhoven, S., Van Huis, A. and Van Loon, J.J.A., 2015. Feed conversion, survival and development, and composition of four insect species on diets composed of food byproducts. PLoS One 10: e0144601.

Papatryphon, E., Petit, J., Kaushik, S.J. and Van der Werf, H.M.G., 2004. Environmental impact assessment of salmonid feeds using life cycle assessment (LCA). AMBIO: A Journal of the Human Environment 33: 316-323.

Parodi, A., De Boer, I.J.M., Gerrits, W.J.J., Van Loon, J.J.A., Heetkamp, M.J.W., Van Schelt, J., Bolhuis, J.E. and Van Zanten, H.H.E., 2020. Bioconversion efficiencies, greenhouse gas and ammonia emissions during black soldier fly rearing - a mass balance approach. Journal of Cleaner Production 271: 122488.

Poore, J. and Nemecek, T., 2018. Reducing food's environmental impacts through producers and consumers. Science 360: 987-992.

Purschke, B., Stegmann, T., Schreiner, M. and Jäger, H., 2017. Pilotscale supercritical $\mathrm{CO}_{2}$ extraction of edible insect oil from Tenebrio molitor L. larvae - influence of extraction conditions on kinetics, defatting performance and compositional properties. European Journal of Lipid Science and Technology 119: 1600134.

Ravindran, R. and Jaiswal, A.K., 2019. Wholesomeness and safety aspects of irradiated foods. Food Chemistry 285: 363-368.

Rebitzer, G., 2005. Enhancing the application efficiency of life cycle assessment for industrial uses. EPFL PP, Lausanne, Switzerland. https://doi.org/10.5075/epfl-thesis-3307 
Rebitzer, G., Ekvall, T., Frischknecht, R., Hunkeler, D., Norris, G., Rydberg, T., Schmidt, W.-P., Suh, S., Weidema, B.P. and Pennington, D.W., 2004. Life cycle assessment part 1. Environment International 30: 701-720.

Roffeis, M., Almeida, J., Wakefield, M., Valada, T., Devic, E., Koné, N., Kenis, M., Nacambo, S., Fitches, E., Koko, G., Mathijs, E., Achten, W. and Muys, B., 2017. Life cycle inventory analysis of prospective insect based feed production in West Africa. Sustainability 9: 1697.

Roffeis, M., Fitches, E.C., Wakefield, M.E., Almeida, J., Alves Valada, T.R., Devic, E., Koné, N., Kenis, M., Nacambo, S., Koko, G.K.D., Mathijs, E., Achten, W.M.J. and Muys, B., 2020. Ex-ante life cycle impact assessment of insect based feed production in West Africa. Agricultural Systems 178: 102710.

Roffeis, M., Muys, B., Almeida, J., Mathijs, E., Achten, W.M.J., Pastor, B., Velásquez, Y., Martinez-Sanchez, A.I. and Rojo, S., 2015. Pig manure treatment with housefly (Musca domestica) rearing - an environmental life cycle assessment. Journal of Insects as Food and Feed 1: 195-214. https://doi.org/10.3920/JIFF2014.0021

Roncolini, A., Milanović, V., Aquilanti, L., Cardinali, F., Garofalo, C., Sabbatini, R., Clementi, F., Belleggia, L., Pasquini, M., Mozzon, M., Foligni, R., Federica Trombetta, M., Haouet, M.N., Serena Altissimi, M., Di Bella, S., Piersanti, A., Griffoni, F., Reale, A., Niro, S. and Osimani, A., 2020. Lesser mealworm (Alphitobius diaperinus) powder as a novel baking ingredient for manufacturing high-protein, mineral-dense snacks. Food Research International 131: 109031.

Rubik, F. and Frankl, P., 2017. The future of eco-labelling: making environmental product information systems effective. Routledge, London, UK.

Salomone, R., Saija, G., Mondello, G., Giannetto, A., Fasulo, S. and Savastano, D., 2017. Environmental impact of food waste bioconversion by insects: application of life cycle assessment to process using Hermetia illucens. Journal of Cleaner Production 140: 890-905.

Schau, E.M. and Fet, A.M., 2008. LCA studies of food products as background for environmental product declarations. The International Journal of Life Cycle Assessment 13: 255-264.

Shorstkii, I., Alles, M.C., Parniakov, O., Smetana, S., Aganovic, K., Sosnin, M., Toepfl, S. and Heinz, V., 2020. Optimization of pulsed electric field assisted drying process of Black soldier fly (Hermetia illucens) larvae. Drying Technology. https://doi.org/10.1080/0737 3937.2020.1819825

Smetana, S., 2020. Life cycle assessment of specific organic waste-based bioeconomy approaches. Current Opinion in Green and Sustainable Chemistry 23: 50-54. https://doi.org/10.1016/j.cogsc.2020.02.009

Smetana, S., Aganovic, K., Irmscher, S. and Heinz, V., 2018a. Agrifood waste streams utilization for development of more sustainable food substitutes. Designing sustainable technologies, products and policies. Springer, Cham, Switzerland, pp. 145-155.

Smetana, S., Ashtari Larki, N., Pernutz, C., Franke, K., Bindrich, U., Toepfl, S. and Heinz, V., 2018b. Structure design of insectbased meat analogs with high-moisture extrusion. Journal of Food Engineering 229: 83-85.

Smetana, S., Leonhardt, L., Kauppi, S.-M., Pajic, A. and Heinz, V., 2020a. Insect margarine: processing, sustainability and design. Journal of Cleaner Production 264: 121670.
Smetana, S., Mathys, A., Knoch, A. and Heinz, V., 2015. Meat alternatives: life cycle assessment of most known meat substitutes. The International Journal of Life Cycle Assessment 20: 1254-1267.

Smetana, S., Mhemdi, H., Mezdour, S. and Heinz, V., 2020b. Pulsed electric field-treated insects and algae as future food ingredients. Pulsed electric fields to obtain healthier and sustainable food for tomorrow. Elsevier, Amsterdam, the Netherlands, pp. 247-266.

Smetana, S., Palanisamy, M., Mathys, A. and Heinz, V., 2016. Sustainability of insect use for feed and food: life cycle assessment perspective. Journal of Cleaner Production 137: 741-751.

Smetana, S., Pernutz, C., Toepfl, S., Heinz, V. and Van Campenhout, L., 2019a. High-moisture extrusion with insect and soy protein concentrates: cutting properties of meat analogues under insect content and barrel temperature variations. Journal of Insects as Food and Feed 5: 29-34. https://doi.org/10.3920/JIFF2017.0066

Smetana, S., Schmitt, E. and Mathys, A., 2019b. Sustainable use of Hermetia illucens insect biomass for feed and food: attributional and consequential life cycle assessment. Resources, Conservation and Recycling 144: 285-296.

Spielmann, M., Scholz, R., Tietje, O. and de Haan, P., 2005. Scenario modelling in prospective LCA of transport systems. Application of formative scenario analysis. The International Journal of Life Cycle Assessment 10: 325-335.

Steubing, B., Mutel, C., Suter, F. and Hellweg, S., 2016. Streamlining scenario analysis and optimization of key choices in value chains using a modular LCA approach. The International Journal of Life Cycle Assessment 21: 510-522.

Suckling, J., Druckman, A., Moore, C.D. and Driscoll, D., 2020. The environmental impact of rearing crickets for live pet food in the UK, and implications of a transition to a hybrid business model combining production for live pet food with production for human consumption. The International Journal of Life Cycle Assessment 25: 1693-1709.

Surendra, K.C., Olivier, R., Tomberlin, J.K., Jha, R. and Khanal, S.K., 2016. Bioconversion of organic wastes into biodiesel and animal feed via insect farming. Renewable Energy 98: 197-202.

Thabrew, L., Wiek, A. and Ries, R., 2009. Environmental decision making in multi-stakeholder contexts: applicability of life cycle thinking in development planning and implementation. Journal of Cleaner Production 17: 67-76.

Thévenot, A., Rivera, J.L., Wilfart, A., Maillard, F., Hassouna, M., Senga-Kiesse, T., Le Féon, S. and Aubin, J., 2018. Mealworm meal for animal feed: environmental assessment and sensitivity analysis to guide future prospects. Journal of Cleaner Production 170: 12601267.

Thomas, C., Grémy-Gros, C., Perrin, A., Symoneaux, R. and Maître, I., 2020. Implementing LCA early in food innovation processes: study on spirulina-based food products. Journal of Cleaner Production 268: 121793.

Tzompa-Sosa, D.A., Yi, L., Van Valenberg, H.J.F. and Lakemond, C.M.M., 2019. Four insect oils as food ingredient: physical and chemical characterisation of insect oils obtained by an aqueous oil extraction. Journal of Insects as Food and Feed 5: 279-292. https:// doi.org/10.3920/JIFF2018.0020 
Ulmer, M., Smetana, S. and Heinz, V., 2020. Utilizing honeybee drone brood as a protein source for food products: life cycle assessment of apiculture in Germany. Resources, Conservation and Recycling 154: 104576.

United Nations Environment Programme and the Society of Environmental Toxicology and Chemistry (UNEP/SETAC), 2011. Global guidance principles for life cycle assessment databases. A basis for greener processes and products. UNEP, Geneva, Switzerland.

United Nations Environment Programme and the Society of Environmental Toxicology and Chemistry (UNEP/SETAC), 2012. Greening the economy through life cycle thinking ten years of the UNEP/SETAC life cycle initiative. UNEP, Geneva, Switzerland, $64 \mathrm{pp}$.

Van der Weele, C., Feindt, P., Van der Goot, A., Van Mierlo, B. and Van Boekel, M., 2019. Meat alternatives: an integrative comparison. Trends in Food Science \& Technology 88: 505-512.

Van Huis, A., Van Itterbeeck, J., Klunder, H., Mertens, E., Halloran, A., Muir, G. and Vantomme, P., 2013. Edible insects. FAO forestry paper. Food and Agriculture Organization of the United Nations, Rome, Italy, 201 pp.

Van Zanten, H.H.E., Bikker, P., Meerburg, B.G. and De Boer, I.J.M., 2018. Attributional versus consequential life cycle assessment and feed optimization: alternative protein sources in pig diets. The International Journal of Life Cycle Assessment 23: 1-11.

Van Zanten, H.H.E., Mollenhorst, H., Oonincx, D.G.A.B., Bikker, P., Meerburg, B.G. and De Boer, I.J.M., 2015. From environmental nuisance to environmental opportunity: housefly larvae convert waste to livestock feed. Journal of Cleaner Production 102: 362-369.
Veldkamp, T., Van Duinkerken, G., Van Huis, A., Lakemond, C.M.M., Ottevanger, E., Bosch, G. and Van Boekel, T., 2012. Insects as a sustainable feed ingredient in pig and poultry diets: a feasibility study. Wageningen UR Livestock Research, Wageningen, the Netherlands. Available at: https://www.wur.nl/upload_mm/2/8/0/ f26765b9-98b2-49a7-ae43-5251c5b694f6_234247\%5B1\%5D.

Vignali, G., 2016. Life-cycle assessment of food-packaging systems. In: Muthu, S.S. (ed.) Environmental footprints of packaging. Springer, Berlin, Germany, pp. 1-22.

Wade, M. and Hoelle, J., 2020. A review of edible insect industrialization: scales of production and implications for sustainability. Environmental Research Letters 15: 123013. https:// doi.org/10.1088/1748-9326/aba1c1

Walser, T., Demou, E., Lang, D.J. and Hellweg, S., 2011. Prospective environmental life cycle assessment of nanosilver T-shirts. Environmental Science \& Technology 45: 4570-4578.

Willett, W., Rockström, J., Loken, B., Springmann, M., Lang, T., Vermeulen, S., Garnett, T., Tilman, D., DeClerck, F. and Wood, A., 2019. Food in the anthropocene: the EAT-Lancet commission on healthy diets from sustainable food systems. The Lancet 393: 447-492.

Zamagni, A., Guinée, J., Heijungs, R., Masoni, P. and Raggi, A., 2012. Lights and shadows in consequential LCA. The International Journal of Life Cycle Assessment 17: 904-918.

Zampori, L., Saouter, E., Schau, E., Cristobal Garcia, J., Castellani, V. and Sala, S., 2016. Guide for interpreting life cycle assessment result. Publications Office of the European Union, Luxembourg.

Zorrilla, M. and Robin, N., 2019. Nutrition technologies: offering price competitive black soldier fly protein and oil to the animal feed and pet food sectors. Industrial Biotechnology 15: 328-329. 
